\title{
Biogas Production from Co-Digestion of Poultry Manure and Orange Peel through Thermo- Chemical Pre-Treatments in Batch Fermentation
}

\author{
Misgana Lami*, Meseret Chimdessa $(\mathrm{PhD})^{* *}$ \\ ${ }^{1}$ College of Agriculture and Natural Resources, Madda Walabu University, Ethiopia \\ E-mail; ofbnaf@gmail.com \\ ${ }^{2}$ College of Natural and Computational Science, Haramaya University, Ethiopia
}

\begin{abstract}
The increasing demand for the treatment of organic wastes from municipalities, farming and industrial activities is a great opportunity to convert organic wastes into energy in a form of biogas. With the aim of producing biogas from co-digestion of Poultry Manure (PM) and Orange Peel $(O P)$ a series of experiments were carried out for 21 consecutive days. Five different proportions of $P M$ and $O P(100 \% P M, 75 \% M P+25 \% O P, 50 \% P M+50 \% O P$, $25 \% P M+75 \% O P, 100 \% O P$ ) were used to obtain the suitable mix ratio (which gives maximum biogas production). Having determined the optimum mix ratio, chemical pre-treatment with $\mathrm{CaO}(0.5 \mathrm{~g}, 1.5 \mathrm{~g}$ and $2.5 \mathrm{~g})$ and temperature pre-treatment at 60 and $80{ }^{\circ} \mathrm{C}$ were applied to compare the results with those obtained with non-pre-treated waste. Cumulative biogas production obtained from $75 \% P M+25 \% O P$ was $768 \mathrm{ml}$, whereas $218.33 \mathrm{ml}$ was measured from $100 \% O P$. Increasing the proportion of OP above 25\% decreased the amount of gas production, volatile solids (VS) and total solids (TS) reduction. This indicated that addition of PM to mix ratios improves biogas production.Thus $75 \% P M+25 \%$ OPmix was found to be the optimum mix ratio which resulted in high biogas yield. In thermal pre-treatments, maximum cumulative gas production was measured at $80{ }^{\circ} \mathrm{C}$ pretreated substrate. It exceeded by $11.7 \%$ and $6.6 \%$ over the control and the $60{ }^{\circ} \mathrm{C}$ pre-treated sample respectively. In case of chemical pre-treatments, the highest cumulative biogas yield was obtained from a substrate treated by $2.5 \mathrm{~g}$ $\mathrm{CaO}$ which exceed by 139, 250 and 356 over $1.5 \mathrm{~g} \mathrm{CaO}$, $0.5 \mathrm{~g} \mathrm{CaO}$ and control, respectively. Overall the results indicated that the biogas yield and VS and TS reduction of the 75\%PM+25\%OPmix ratio can be enhanced with the use of thermal and chemical pre-treatments prior to anaerobic digestion.
\end{abstract}

Keywords-Anaerobic Digestion, Biogas, Co-digestion, Pre-treatments, Total solids, Volatile solids, D-limonene.

\section{INTRODUCTION}

Biogas technology is growing as a number of countries are accessing up biogas targets as a main approach for treating a variety of organic wastes. Biogas production decreases environmental pollution through decomposing organic wastes and positively impacts the socio-economy of the society (Lawrence, 2012). Today, utilization of biogas as an alternative energy source is steadily increasing. It accounts for up to $20 \%$ of renewable energy consumption in the European Union. About 52\% of the biogas plants produce biogas from agricultural wastes, and about $36 \%$ are utilizing sewage sludge and the remaining $12 \%$ are landfill treatment plants. Germany is by far the major biogas producer in the world (Bisypln, 2012).

For their economic progress, African countries need sustainable energy supplies. Unreliable energy supply may end up with low level of private investment in African continent. Therefore, improvement in the quality and magnitude of energy services in developing countries is required to meet developmental objectives including the Millennium Development Goals (MDGs). Although reliable regional energy statistics are not readily available, the existing estimates of energy use in Eastern and Southern Africa indicate that there is a significant and persistent dependence on traditional biomass energy technologies and limited use of modern, sustainable energy technologies (Karekezi, 1994).

Biomass in the form of mainly fuel wood and charcoal is the dominant energy source in Sub-Saharan Africa. Though it appears cheap, overexploitation of this biomass leads to serious negative environmental consequences. Fossil energy sources are the most widely used energy supplies in the world today. However, the increased prices of oil and increased awareness of climate changes is promoting the use of alternative environmentally friendly renewable energy sources such as biogas (Khanal, 2008). 
Traditionally, biogas has been used as fuel to support the process temperatures in anaerobic digesters. Another alternative use is that the gas is burned in an engine generator of combustion to produce electricity in biogas plants. It has also been used as fuel for cooking, light and vehicles (Khanal, 2008).

Due to the complex physical and chemical nature of lignocellulosic substrates, their complete biodegradation cannot be achieved in anaerobic digesters to result in high biogas yield (Rafiqueet al, 2010). To overcome biodegradability problem, some pre-treatment methods can be employed (Bruni, 2010). Pre-treatments, for example, biological (Zhonget al., 2011), mechanical (Angelidaki and Ahring, 1999), chemical (Devlin et al., 2011),thermal (Mladenovskaet al., 2006) and combination of these treatments have been done to facilitate the biogas production by overcoming the limitation of hydrolysis, which include the solubilization and biodegradation of hemi-cellulosic and lignin parts of the substrates. Rafique (2010) reported that thermo-chemical pretreatments have a great impact on biogas production with a maximum enhancement of $78 \%$ for biogas and $60 \%$ for methane. Thermal pretreatment also has effect on biogas production with a maximum enhancement of $28 \%$ for biogas and $25 \%$ for methane. This indicates that pretreatment of substrates urgently needs further investigation.

Biogas technology was introduced in Ethiopia as early as 1979, when the first batch type digester was constructed at the Ambo Agricultural College. In the last two and half decades around 1000 biogas plants, ranging in size from $2.5 \mathrm{~m}^{3}$ to $200 \mathrm{~m}^{3}$ have beenconstructed in households, community and governmental institutions in various parts of the country (EREDPC, 2008). In Ethiopia, biogas production from different organic materials. However, no research has been done on the effect of different pretreatments of poultry waste and orange peel on biogas production.

\section{General Objective was to:}

$>$ Examine the effect of thermal pre-treatments on biogas production from poultry manure and orange peel in sole or co-digestion.

\section{Specific Objectives were to:}

1. Characterize poultry manure and orange peel in terms of the total solids (TS), volatile and fixed solids (VS), moisture content,organic Carbon and $\mathrm{pH}$ before and after anaerobic digestion.

2. Evaluate the biogas yield of single and mixed substrates of orange peel and poultry manure.

3. Assess the effect of thermal and chemical pretreatments on biogas yield

\section{MATERIALS AND METHODS}

\subsection{Description of the Study Area}

The study was conducted in Microbiology Laboratory of Haramaya University Main Campus, which is located at a latitude of $9^{\circ} 26^{\prime} \mathrm{N}$ and longitude of $42^{\circ} 03^{\prime} \mathrm{E}$ and has an altitude of 1980 meters above sea level (FAO, 1990).

\subsection{Design of Experiments and Preparation of Substrates}

The study was carried out by using two experimental phases: (i) anaerobic digestion of five substrates without pre-treatments and (ii) anaerobic digestion of the best performing substrate of first phase with thermal and chemical pre-treatments. The five substrates that were used for anaerobic digestion without pre-treatments were poultry manure (PM) and orange peel (OP) in sole or mixing at different proportions as follows; 100\% PM, 75\%:25\% mix of PM: OP, 50\%:50\% mix of PM: OP, 25\%:75\% mix of PM: OP and $100 \%$ OP. For further experiment and second phase of experiment the highest biogas yielding substrate was selected and pre-treated by thermal and chemical treatments, i.e. anaerobic digestion after thermal and chemical pre-treatments. The experimental design was completely randomized design. That means the treatments were arranged randomly in the laboratory and done in three replicates.

\subsection{Feedstock and Inoculum}

Two types of lignocellulosic biomass, poultry manure and orange peel were used in this study. Poultry manure was obtained from Haramaya University animal farm, i.e.fresh manure about $(4 \mathrm{~kg})$ was randomly collected. Orange peel waste $(4 \mathrm{~kg})$ was collected from local market around Haramaya Universitywashed with water and cut into pieces using scissors in the laboratory in order to make it easier for digestion. The prepared orange peels were added into poultry manure in different proportions and stored at $4^{\circ} \mathrm{C}$ for usage as feed.

To start up anaerobic process, rumen fluid was used as inoculum (Sunarsoet al., 2012). For this experiment, fresh rumen fluid was collected from the nearby slaughter house and filtered through a cloth of $0.5 \mathrm{~mm}$ sieve diameter to separate solid content from slurry. Prior to use, the inoculum was starved for one week by incubating at $38^{\circ} \mathrm{Cto}$ remove the easily degradable VS present in inoculums (Lo NieeLiew, 2011).

\subsection{Analyses of Physico-chemical Characteristics of Substrates}

Both poultry manure and orange peel were analysed for TS, VS, moisture content and $\mathrm{pH}$ before and after AD process 
based on the Standard Methods for the Examination of Water and Wastewater (APHA, 1999).

\subsubsection{Total solids}

First a clean evaporating dish was oven-dried (at $105^{\circ} \mathrm{C}$ for 1hour), cooled in a desiccator and weighed immediately before use. Sample of substrate (10 g) was placed on the evaporating dish and put in an oven (Contherm 260M) at $105^{\circ} \mathrm{C}$ using a crucible to evaporate for 24 hours. After 24 hours, the crucible was taken out from the oven, cooled in desiccators and weighed using electronic balance (PB602). Thereafter, the percentage of TS was calculated using the following formula (APHA 2540 B, 1999).

$$
\% \mathrm{TS}=\frac{\mathrm{mDS}}{\mathrm{mFS}} \times 100
$$

Where,

$\% \mathrm{TS}=$ percentage of total solids

$\mathrm{mDS}=$ mass of dry sample (final weight) in gram

$\mathrm{mFS}=$ mass of fresh sample in gram

Then percentage of TS removal was calculated using the formula indicated below.

$$
\% \mathrm{TS} \text { removal }=\frac{\mathrm{TSi}-\mathrm{TSf}}{\mathrm{TSi}} \times 100
$$

Where,

Tsi=initial total solids before digestion (\%)

Tsf=final total solids after digestion (\%)

\subsubsection{Volatile and fixed solids}

Once the TS was determined, the oven dried sample was ignited at $550^{\circ} \mathrm{C}$ in a muffle furnace (BiBBY, Stuart) for 3 hours to determine the volatile and fixed solids. The following formula was employed to calculate the percentage of volatile solids content of the TS (APHA 2540 E, 1999).

$$
\% \mathrm{VS}=\frac{\mathrm{mDS}-\mathrm{m}(\mathrm{ash})}{\mathrm{mDS}} \times 100
$$

Where,

$\% \mathrm{VS}=$ percentage of volatile solids

$\mathrm{mDS}=$ mass of dry solids in gram

$\mathrm{m}(\mathrm{ash})=$ remaining mass after ignition $=$ fixed solid in grams.

i.e., $\mathrm{TS}=\mathrm{VS}+$ fixed solids

Then percentage VS removal was calculated using the equation below.

$$
\% \mathrm{VS} \text { removal }=\frac{\mathrm{VSi}-\mathrm{VSf}}{\mathrm{VSi}} \times 100
$$

Where,

Vsi= initial volatile solids before AD (\%)

Vsf=final volatile solids after AD (\%)

\subsubsection{Moisture content determination}

To determine the percentage of moisture content (MC) in the samples, $10 \mathrm{~g}$ of fresh substrate was dried in an oven (Contherm 260M) at $105{ }^{\circ} \mathrm{C}$ for 24 hours and reweighed. The moisture content was then calculated as follows (APHA 2540 E, 1999).

$$
\% \mathrm{MC}=\frac{\mathrm{W}-\mathrm{D}}{\mathrm{W}} \times 100
$$

Where,

$$
\begin{aligned}
& \mathrm{MC}=\text { moisture content } \\
& \mathrm{W}=\text { initial weight of sample in grams, } \\
& \mathrm{D}=\text { weight of sample after drying at } 105
\end{aligned}
$$

${ }^{\circ} \mathrm{C}$ in grams

\subsubsection{Determination of $\mathrm{pH}$}

The initial $\mathrm{pH}$ of each sample was measured directly using digital $\mathrm{pH}$ meter before and after AD (HANNA HI 8314). In the case of before $\mathrm{AD}$, an electrode was inserted into samples of substrate that was diluted using distilled water before inoculation of rumen fluid and the $\mathrm{pH}$ values of the contents of digesters were buffered between 6.8 and 7.4 which is the optimal range for methanogenic bacteria (Arogo et al., 2009). Measurement of $\mathrm{pH}$ after AD was also done using $\mathrm{pH}$ electrode which was inserted into samples of substrate that is digested in $\mathrm{AD}$ process.

\subsubsection{Organic carbon}

The carbon content of the substrates was obtained from volatile solids data using an empirical equation as reported by Badger et al. (1979).

$$
\% \text { Carbon }=\frac{\% \mathrm{VS}}{1.8}
$$

Where, $\mathrm{VS}=$ Volatile solids

\subsection{Anaerobic Digestion of Substrates without Pre- treatment}

The experiments were conducted in batch mode in $0.5 \mathrm{~L}$ digester from poultry manure and orange peel which were prepared in five different proportions as indicated above. As suggested by Tchobanoglouset al. (1993), substrates were mixed with appropriate amount of distilled water and inoculum to achieve the recommended $(8 \% \mathrm{w} / \mathrm{w})$ total solids content in the fermentation slurry. The total amount of liquid (distilled water and rumen fluid) needed to be added to the digester was then determined by the formula;

$$
\mathrm{Y}=\frac{m T S-8 \% X}{8 \%}
$$


Where,

mTS $=$ mass of total solids

$\mathrm{X}=$ mass of fresh substrate

$\mathrm{Y}=$ mass of fluid (distilled water and rumen fluid) to be added to get $8 \%$ total solids in the digester.

Then, by fixing the amount of inoculum $(100 \mathrm{~mL})$ that was added finally to facilitate digestion, the amount of distilled water that has to be added was then determined using the formula;

$\mathrm{Z}=\mathrm{Y}-100$

Where,

$\mathrm{Z}=$ amount of distilled water
$\mathrm{Y}=$ total amount of liquid (distilled water and rumen fluid).

The temperature of the biodigester was kept at mesophilic condition $\left(38^{\circ} \mathrm{C}\right)$ by keeping in oven (Knottier, 2003). The $\mathrm{pH}$ of the digesters was maintained between 6.8 and 7.4 by adding buffer solution (Yadvikaet al., 2004). The digestion process lasted for about 21 days and biogas yield was measured every day starting from the first day after the substrates were arranged for AD.

\subsection{Thermal and Alkali Pre-treatments}

For the choice of pre-treatment, the different mix ratios of untreated substrates were identified and compared based on their ability to produce highest yield of biogas production and VS and TS reduction. Therefore, the mix ratio of the untreated substrate that resulted in highest biogas yield was taken as the optimal mix-ratio and used for the next pretreatment experiments. The pre-treatments were performed before digestion to check whether or not pre-treatments increase the efficiency of biogas production.

2.6.1. Thermal pre-treatment and digestion of high yielding substrate combination

According to Rafique (2010), thermal pretreatment showed enhancement in the temperature range $50-100^{\circ} \mathrm{C}$, with maximum enhancement at $100^{\circ} \mathrm{C}$, having $28 \%$ biogas and $25 \%$ methane increases. For this reason, the slurry containing the optimum non-treated substrate mix-ratio and the corresponding volume of distilled water were added into $0.5 \mathrm{~L}$ flasks. Since temperature below $60^{\circ} \mathrm{Cis}$ usually considered as a pre-digestion step rather than pre-treatment, 60 and $80{ }^{\circ} \mathrm{C}$ were selected. After covering the flasks with plastic film, they were treated with temperatures of 60 and $80^{\circ} \mathrm{C}$ for 3 hours by keeping in water bath with intermittent gentle shaking to ensure the homogeneity of temperatures in the flasks (Bonmatiet al., 2001). The sample without thermal pre-treatment is used as control. Then all the slurry was kept for 24 hours in a refrigerator at $4^{\circ} \mathrm{C}$ before the addition of $100 \mathrm{~mL}$ inoculum.

The total amount of liquid (distilled water and rumen fluid) needed to be added to the digester was then determined using the same formula indicated in section 3.5 and the same is true for $\mathrm{pH}$ and temperature.

\subsubsection{Alkali pre-treatment and digestion of high yielding substrate combination}

In this study, Slurry containing the optimum non-treated substrate mix-ratio and the corresponding volume of distilled water was added into $0.5 \mathrm{~L}$ flasks. Then, different concentrations of $\mathrm{CaO}(0.5,1.5$ and $2.5 \mathrm{~g}$ in solution form) were mixed for 1 hour using rotary shaker. After chemical pre-treatment, the $\mathrm{pH}$ of all treatments was reduced to neutral $\left(\mathrm{pH} \sim 7.0\right.$ ) by adding $6 \mathrm{~N} \mathrm{H}_{2} \mathrm{SO}_{4}$ (Rafiqueet al., 2010). After 24 hours of stay in the refrigerator, equal amount of inoculum $(100 \mathrm{~mL})$ was added to the slurry to adjust the TS to $8 \%$. Digester without $\mathrm{CaO}$ addition was used as a control.

The total amount of liquid and amount of distilled water was calculated as mentioned above, and same is true for temperature and $\mathrm{pH}$ of the slurry.

\subsection{Digester Configuration and Setup for Biogas Production}

Thirty (15 for co-digestion without pre-treatment, 9 for chemical pre-treatment and 6 for thermal pre-treatment) anaerobic digesters (plastic bottle) were constructed for bench-scale experiments with which biogas was produced out of the degradation of substrates in $0.5 \mathrm{~L}$ digester. Degradation of the substrate was accomplished in sealed three bottles each with a capacity of $0.5 \mathrm{~L}$ which were arranged in order in such a way that the first bottle contained slurry, the middle contained acidified brine solution and the last was used for collecting the brine solution that was expelled out from the second container.

The acidified brine solution was prepared by adding $\mathrm{NaCl}$ to distilled water until a supersaturated solution was formed to prevent the dissolution of biogas in the water. Three drops of sulphuric acid were added using a dropper to acidify the brine solution. All the three containers were interconnected with a plastic tube having a diameter of $1 \mathrm{~cm}$. The tube connecting the first bottle to the second was fitted just above the slurry in the first bottle to help gas collection. Thus, the biogas produced by fermentation of the slurry was driven from the first bottle to the second bottle that contained a brine solution so as to displace a volume of the 
brine solution equivalent to the volume of biogas that was produced.

The lids of all digesters were sealed tightly using superglue in order to control the entry of oxygen and loss of biogas. Daily biogas production was measured following the method suggested by Itodoet al (1992). As biogas production was commenced in the fermentation chamber, it was delivered to the second chamber which contained the acidified brine solution. Since the biogas is insoluble in the solution, a pressure build-up provides the driving force for displacement of the solution. The displaced solution was measured to represent the amount of biogas produced. The temperature of all digesters was maintained at $38^{\circ} \mathrm{C}$ by keeping in an incubator, which represents mesophilic condition.

\subsection{Data Analysis}

Data were analysed by using analysis of variance (one-way ANOVA) using SAS version 9.1. Fishers Least Significant Difference (LSD) was used to investigate statistical significance between the different treatments, whereas paired samples T-test was used to investigate statistical significance within a treatment. The statistical significance level was selected at $\mathrm{p}$-value $<0.05$

\section{RESULTS AND DISCUSSION}

\subsection{Physico-chemical Characteristics of the Untreated} Substrates

The Physico-chemical characteristics of both PM and OP in sole or mixed for AD were determined before and after AD, and among the different mix ratios.

Table.1: Comparison of $\mathrm{pH}, \%$ organic carbon and \%MC between before and after AD and among different mix ratios (values are mean $\pm S E, n=3$ )

\begin{tabular}{|c|c|c|c|c|c|c|}
\hline \multirow[t]{2}{*}{ Treatments } & \multicolumn{6}{|l|}{ Parameters } \\
\hline & $\mathrm{pH}$ & & $\% \mathrm{C}$ & & & $\% \mathrm{MC}$ \\
\hline & Initial & Final & Initial & Final & Initial & Final \\
\hline A & $6.89 \pm 0.01^{\mathrm{Aa}}$ & $8.15 \pm 0.01^{\mathrm{Eb}}$ & $10.14 \pm 0.01^{\mathrm{Da}}$ & $8.52 \pm 0.01^{\mathrm{Db}}$ & $76.40 \pm 0.03^{\mathrm{Ea}}$ & $80.60 \pm 0.05^{\mathrm{Eb}}$ \\
\hline B & $6.82 \pm 0.00^{\mathrm{Ba}}$ & $8.46 \pm 0.02^{\mathrm{Db}}$ & $10.69 \pm 0.01^{\mathrm{Ea}}$ & $7.68 \pm 0.00^{\mathrm{Eb}}$ & $76.20 \pm 0.06^{\mathrm{Da}}$ & $82.20 \pm 0.03^{\mathrm{Db}}$ \\
\hline $\mathrm{C}$ & $6.51 \pm 0.08^{\mathrm{Ca}}$ & $8.64 \pm 0.02^{\mathrm{Cb}}$ & $11.36 \pm 0.01^{\mathrm{Ca}}$ & $8.87 \pm 0.01^{\mathrm{Cb}}$ & $74.90 \pm 0.03^{\mathrm{Ba}}$ & $78.80 \pm 0.01^{\mathrm{Cb}}$ \\
\hline $\mathrm{D}$ & $6.13 \pm 0.04^{\mathrm{Da}}$ & $8.73 \pm 0.06^{\mathrm{Bb}}$ & $11.74 \pm 0.02^{\mathrm{Ba}}$ & $9.19 \pm 0.02^{\mathrm{Bb}}$ & $74.10 \pm 0.02^{\mathrm{Ca}}$ & $77.40 \pm 0.05^{\mathrm{Bb}}$ \\
\hline $\mathrm{E}$ & $5.53 \pm 0.02^{\mathrm{Ea}}$ & $8.83 \pm 0.03^{\mathrm{Ab}}$ & $12.02 \pm 0.01^{\mathrm{Aa}}$ & $9.80 \pm 0.01^{\mathrm{Ab}}$ & $73.35 \pm 0.04^{\mathrm{Aa}}$ & $77.00 \pm 0.06^{\mathrm{Ab}}$ \\
\hline
\end{tabular}

Means followed by different small letters in row are significant at 0.05 probability levels for paired samples $\mathrm{T}$ test within treatment. Means followed by different capital letter in column are significantly different at 5\% level of significance between treatments.

$\mathrm{A}=100 \% \mathrm{PM}, \mathrm{B}=75 \% \mathrm{PM}+25 \% \mathrm{OP}, \mathrm{C}=50 \% \mathrm{PM}+50 \% \mathrm{OP}, \mathrm{D}$ $=25 \% \mathrm{PM}+75 \% \mathrm{OP}$ and $\mathrm{E}=100 \% \mathrm{OP}$.

$\mathrm{pH}$ is one of the factors that affect anaerobic digestion. It is important to adjust the $\mathrm{pH}$-value in the optimal range because anaerobic performance is affected by slight $\mathrm{pH}$ deviations from the optimum. A significant decrease in growth rate of methane forming bacteria occurs if the value of $\mathrm{pH}$ is below 6.6. Furthermore, high alkaline $\mathrm{pH}$ can cause disintegration of microbial granules and consequently, result in the failure of anaerobic digestion (Ward, 2008). The $\mathrm{pH}$ of $100 \%$ PM slurry before anaerobic digestion was about $6.89 \pm 0.01$, whereas that of $100 \%$ OP was $5.53 \pm 0.02$. So, $\mathrm{pH}$ of poultry manure alone is almost optimal for biogas production, but $\mathrm{pH}$ of OP alone is not optimal for anaerobic digestion as it falls below 6.8. When the substrates were mixed, it resulted in the rise of $\mathrm{pH}$ compared to that of OP alone. The $\mathrm{pH}$ was found to increase significantly with increasing of PM proportion in the mix, suggesting that PM helps to maintain the $\mathrm{pH}$ to meet the optimum required. As volatile acid concentrations increase, the $\mathrm{pH}$ in the digester decreases. Thus, mixing of substrates is a good way of adjusting the $\mathrm{pH}$ value to the optimum (Hills and Roberts, 1981).

Comparison of $\mathrm{pH}$ values between before and after $\mathrm{AD}$ showed that $\mathrm{pH}$ values are significantly increased for all treatments $(P<0.05)$ (Table 1$)$. Maximum $\mathrm{pH}$ value was 8.83 whereas minimum value was 8.15 . This indicated that as the proportion of OP increased within the sample, $\mathrm{pH}$ value also increased accordingly (Table 1). The reason for the increment of the $\mathrm{pH}$ values after $\mathrm{AD}$ may be attributed to production of alkali compounds, such as ammonium ions during the degradation of organic compounds in the digester (Gerardi, 2003). The $\mathrm{pH}$ value of the rumen fluid used in all experiments was relatively higher than both substrates $(\mathrm{pH}=7.51)$. This shows that the rumen content used may have high ammonia concentration. Thus, in addition to initiating the start up in the digestion process, the rumen 
fluids were used to adjust the $\mathrm{pH}$ of both single and mixed substrates, especially OP alone and mix ratios containing high content of OP.

The moisture content of 100\% PM, 75\% PM+25\% OP, $50 \%$ $\mathrm{PM}+50 \% \mathrm{OP}, 25 \% \mathrm{PM}+75 \% \mathrm{OP}$ and $100 \% \mathrm{OP}$ before $\mathrm{AD}$ were $\quad 76.40 \pm 0.03 \%, \quad 76.20 \pm 0.06 \%, \quad 74.90 \pm 0.03 \%$, $74.10 \pm 0.02 \%$, and $73.35 \pm 0.04 \%$, respectively. This indicates that PM contains high moisture content than OP and mixing of substrates might balance the moisture content of the digester. Significant differences were observed between before and after $\mathrm{AD}$ in all treatments (Paired samples T-test, $P<0.05)$. The moisture content in all the substrates was found to be high to facilitate efficient degradation of the substrates as bacteria can easily access liquid substrate for relevant reactions to take place easily (Buysman, 2010). Since studies on the most favourable percentage of total solids for biogas productions suggest $8 \%$ as the optimum TS, the initial moisture content of substrates used for this study was not optimal for wet anaerobic digestion process (Tchobanoglouset al., 1993). Therefore, dilution is required to bring the total solids percentage to $8 \%$.

There was a significant difference between treatments in both before and after $\mathrm{AD}$ in $\% \mathrm{C}$ (Table 1). The study revealed that the percentage degradation of organic carbon for $75 \% \mathrm{PM}+25 \%$ OP was higher than all treatments (from $10.69 \pm 0.01$ to $7.68 \pm 0.00$, i.e., $30.1 \%$ reduction) (Table 1 ). Organic carbon can be removed in anaerobic digesters either by being converted to cellular materials for growth and reproduction of bacteria or through biogas production (Gerardi, 2003). Therefore, the decrease in Carbon reflects the degradation process during anaerobic digestion (Devlin et al, 2011). The results also revealed that there were differences in percentage organic carbon in all mix ratios before and after $\mathrm{AD}(P<0.05)$. This shows that mixing balances the percentage of organic carbon of substrates in the digester as the two substrates (PM and OP) contain different carbon content.

3.2. Analysis of TS and VS values of Untreated Substrates before and after AD

Table.2: Comparison of TS \% and VS \% between before and after AD and among the mix ratios (values are mean $\pm S E, n=3$ ).

\begin{tabular}{lllll}
\hline & \multicolumn{4}{c}{ Parameters } \\
\cline { 2 - 5 } & Initial TS & Final TS & Initial VS & Final VS \\
\hline $100 \%$ PM & $23.55 \pm 0.02^{\mathrm{Db}}$ & $19.44 \pm 0.02^{\mathrm{Da}}$ & $18.25 \pm 0.02^{\mathrm{Da}}$ & $15.34 \pm 0.02^{\mathrm{Db}}$ \\
$75 \% \mathrm{PM}+25 \%$ OP & $23.82 \pm 0.34^{\mathrm{Db}}$ & $17.75 \pm 0.02^{\mathrm{Ea}}$ & $19.24 \pm 0.02^{\mathrm{Ea}}$ & $13.82 \pm 0.01^{\mathrm{Eb}}$ \\
$50 \% \mathrm{PM}+50 \%$ OP & $25.07 \pm 0.03^{\mathrm{Cb}}$ & $21.24 \pm 0.02^{\mathrm{Ca}}$ & $20.45 \pm 0.02^{\mathrm{Ca}}$ & $15.96 \pm 0.01^{\mathrm{Ca}}$ \\
$25 \%$ PM+75\% OP & $25.93 \pm 0.03^{\mathrm{Bb}}$ & $22.64 \pm 0.01^{\mathrm{Ba}}$ & $21.13 \pm 0.03^{\mathrm{Ba}}$ & $16.54 \pm 0.02^{\mathrm{Bb}}$ \\
$100 \%$ OP & $26.45 \pm 0.02^{\mathrm{Ab}}$ & $23.04 \pm 0.01^{\mathrm{Aa}}$ & $21.64 \pm 0.01^{\mathrm{Aa}}$ & $17.64 \pm 0.01^{\mathrm{Ab}}$ \\
\hline
\end{tabular}

Means followed by different small letters in row are significant at 0.05 probability levels for paired samples $\mathrm{T}$ test within treatment. Means followed by different capital letter in column are significantly different at $5 \%$ level of significance between treatments. $\mathrm{PM}=$ poultry manure, $\mathrm{OP}=$ orange peel.

Significant differences were observed between treatments in $\%$ TS and \%VS both in before and after AD (Table 2). Total solid content of all mixes before inoculation and digestion fall between $23.55 \pm 0.02 \%$ (i.e., 2.36 gram of TS from 10gram sample) and $26.45 \pm 0.02 \%$. Maximum TS was measured from $100 \% \mathrm{OP}$, but the minimum TS was recorded from 100\% PM as shown in the table above (Table 2). The TS content of $23.55 \%$ of $\mathrm{PM}$ used in this experiment is in the range of 10 to $30 \%$ TS reported by Braun (1982). Some agro-industrial wastes may contain less than $1 \% \mathrm{TS}$, while others contain high TS content of more than $20 \%$. Thus, the TS content of OP alone was in this range. This results in some substrates being able to be fermented only when mixed with other substrate or diluted. After $\mathrm{AD}$, values of $\mathrm{TS}$ significantly decreased in all substrate types (Table 2). However, high decrement was observed in $75 \% \mathrm{PM}+25 \% \mathrm{OP}$ which was 6.07 . The result also revealed that significant differences were observed between substrates in VS before and after AD. High reduction of VS was measured in $75 \% \mathrm{PM}+75 \% \mathrm{OP}$ mix substrates compared to the rest of substrates after $\mathrm{AD}$ (Table 2). The TS and VS values before digestion was found to vary significantly $(P<0.05)$ with increasing of OP proportion in the mix, suggesting that mixing helps to adjust the TS and VS. Removal of VS after AD suggests its conversion to biogas. Total solids and volatile solids destruction is a good parameter for evaluating the efficiency of anaerobic digestion (Abuabaker and Ismail, 2012).

3.3. Average Daily and Cumulative Biogas Production of Untreated Substrates 
Even though the digesters contained different mix ratios of $\mathrm{PM}$ and $\mathrm{OP}$, and the volume biogas produced varied with substrate mixture, gas production was noticed from the very initial day of the experiment (Figure 1, Appendix Table 1). Initially, the digester with $\mathrm{PM}$ alone and $75 \% \mathrm{PM}+25 \% \mathrm{OP}$ produced higher amount of biogas than other digesters (Figure 1). This could happen due to the presence of higher amount of readily biodegradable organic matter and native anaerobic microbes in the PM (Hobson, 1981; Yeole and Ranande, 1992). Thus, biogas production is a function of

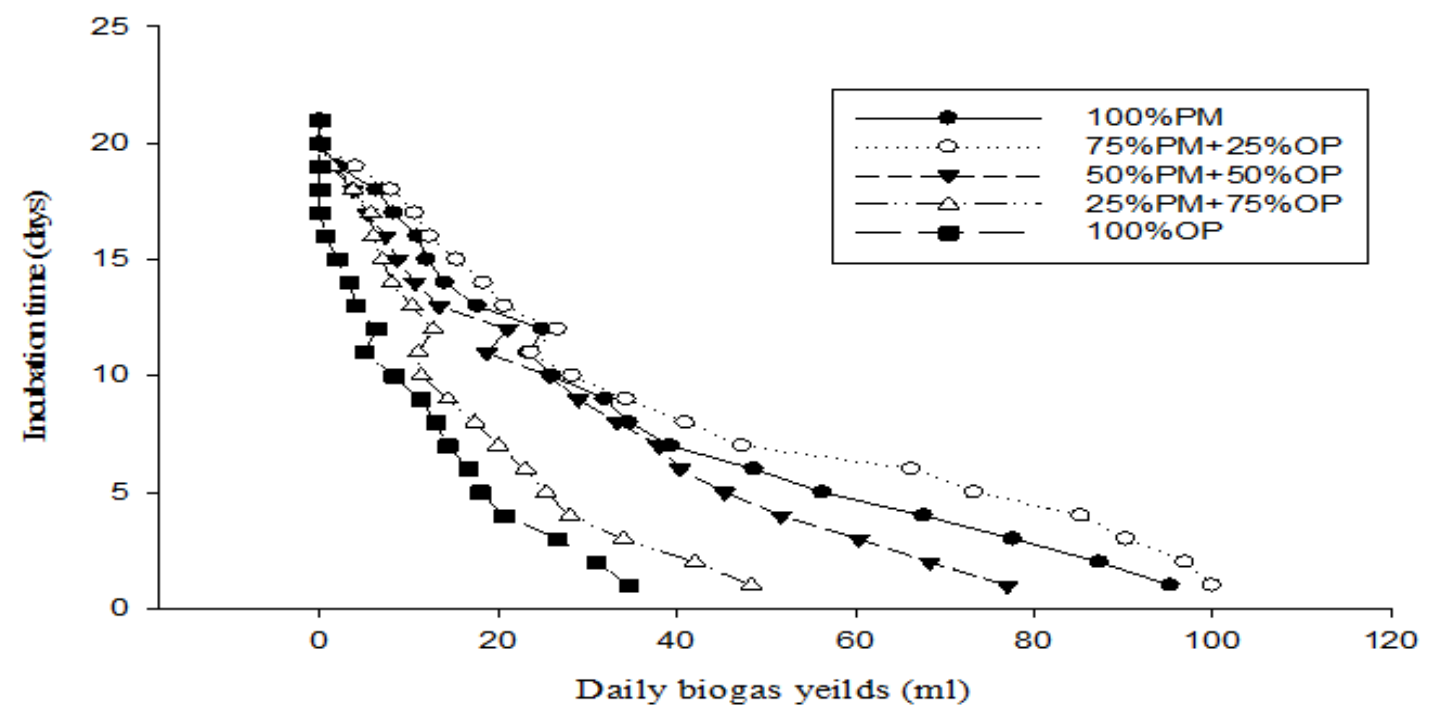

$\mathrm{PM}=$ Poultry manure, $\mathrm{OP}=$ Orange peel

Fig.1: Daily mean biogas yield of the different substrate combinations.

There was a significant difference between the substrates in an overall biogas yield (Figure $2, p<0.05$ ) even though closer result was obtained from $100 \% \mathrm{PM}$ and $50 \% \mathrm{PM}+50 \% \mathrm{OP}$. High production of gas was recorded from a digester containing PM alone and other digesters having equal or more than $50 \%$ of PM as a co-substrate (Figure 2). However, the highest production of gas was observed from the mix ratio of $75 \% \mathrm{PM}+25 \% \mathrm{OP}$. From $10 \mathrm{~g}(75 \% \mathrm{PM}+25 \% \mathrm{OP}), 768 \mathrm{ml}$ (Appendix table 1) of biogas was produced which was $549 \mathrm{ml}$ higher than $100 \% \mathrm{OP}$, that has produced $218.33 \mathrm{ml}$ of cumulative biogas. According to Kapraju and Rintala (2006) the performance of digesters could be considerably improved by means of co-substrate addition and hence can be used to increase the efficiency of degradation and biogas production.

Low gas production obtained from digesters having high proportion of OP and the lowest production of gas was the feedstock's organic content and its biodegradability (Macias-Corral et al., 2008).

Production of gas had gradually decreased starting from the first day in all digesters except in PM alone. This might be due to the declining of readily decomposable substrate (Ahnet al., 2009) and/or an increase in ammonium concentration that may resulted in an increased $\mathrm{pH}$ values (Hansen et al., 1999). Gas production continued until day 19 and fallen sharply to $0 \mathrm{ml}$ after day 20 for digesters having PM alone and PM as co-substrate, but it stopped after day 17 for digester containing OP alone. 


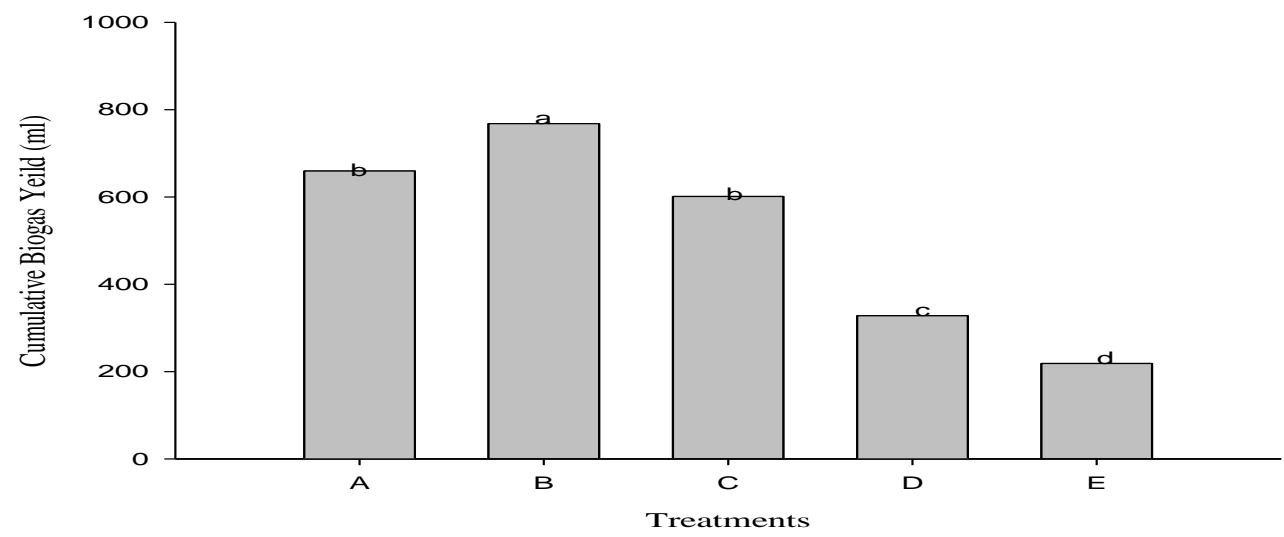

Fig.2: Cumulative biogas yield of the different substrate combinations (Values are mean $\pm S E$ ). Bars with different letters indicate significant differences between means while those with same letters show no significant difference between means.

$A=100 \% P M, B=75 \% P M+25 \% O P, C=50 \% P M+50 \% O P, D=25 \% P M+75 \% O P, E=100 \% O P$. (PM=Poultry manure,

\section{$O P=$ Orange peel)}

\subsection{Physico-chemical Characteristics of Temperature Pre-treated Substrate}

$\mathrm{pH}$ values of the substrates for the three temperature treatments (control, $60^{\circ} \mathrm{C}$ and $80^{\circ} \mathrm{C}$ ) was within the range of $6.82 \pm 0.01$ to $7.43 \pm 0.01$ before digestion (Table 3). This $\mathrm{pH}$ range is optimal for biogas production. Optimal $\mathrm{pH}$ for biogas production is neutral and when $\mathrm{pH}$ is $<6$ or $>8$, fermentation process will be inhibited or ceased at all because of its toxic effect on the methanogenic bacteria, which produce methane gas (Thy et al., 2003). The $\mathrm{pH}$ value of rumen fluid used in this experiment is almost neutral (7.51).

Table.3: Physico-chemical features of blended PM and OP at 75\%: 25\% ratio for thermal pre-treatment test before and after AD (values are mean $\pm S E, n=3$ ).

\begin{tabular}{lllll}
\hline Treatments & Parameters & & \\
\cline { 2 - 5 } & Initial $\mathrm{pH}$ & Final $\mathrm{pH}$ & \% initial organic C & \% final organic C \\
\hline Control & $6.82 \pm 0.01^{\mathrm{bA}}$ & $8.45 \pm 0.01^{\mathrm{aA}}$ & $10.69 \pm 0.01^{\mathrm{aA}}$ & $7.68 \pm 0.01^{\mathrm{bA}}$ \\
$60^{\circ} \mathrm{C}$ & $7.41 \pm 0.01^{\mathrm{bB}}$ & $8.45 \pm 0.01^{\mathrm{aA}}$ & $10.56 \pm 0.05^{\mathrm{aA}}$ & $3.65 \pm 0.02^{\mathrm{bB}}$ \\
$80^{\circ} \mathrm{C}$ & $7.43 \pm 0.01^{\mathrm{bB}}$ & $8.46 \pm 0.01^{\mathrm{aA}}$ & $10.59 \pm 0.03^{\mathrm{aA}}$ & $3.17 \pm 0.01^{\mathrm{bC}}$ \\
\hline
\end{tabular}

Means followed by different small letters in row are significant at 0.05 probability levels for paired samples $\mathrm{T}$ test within treatment. Means followed by different capital letter in column are significantly different at $5 \%$ level of significance between treatments.

The result showed that the values of $\mathrm{pH}$ were slightly increased as the temperature of the substrate rose up from control to $80^{\circ} \mathrm{C}$. This may be explained by the solubilisation of compounds such as proteins during thermal pre-treatment (Carrèreet al., 2009). So this indicates that temperature and $\mathrm{pH}$ are directly proportional to each other, i.e., as temperature increases $\mathrm{pH}$ increases and vice versa up to a certain point. There was no significant difference in $\mathrm{pH}$ values between the thermal treatments after $\mathrm{AD}(P>0.05)$ (Table 3). Before $\mathrm{AD}, \mathrm{pH}$ value of the control showed significant difference than the two thermal treatments compared to initial $\mathrm{pH}(\mathrm{p}<0.05)$. The final alkaline $\mathrm{pH}$ observed after digestion might be explained by the formation of $\left(\mathrm{NH}_{4}\right)_{2} \mathrm{CO}_{3}$ (Georgacakiset al., 1982).

The result revealed that $\% \mathrm{C}$ reduced in both thermal treatments $\left(60^{\circ} \mathrm{C}\right.$ and $\left.80^{\circ} \mathrm{C}\right)$ before $\mathrm{AD}$. The percentage reduction was $65.4 \%$ and $70 \%$ for $60^{\circ} \mathrm{C}$ and $80^{\circ} \mathrm{C}$ respectively. The results also showed that there are significant differences in percentage organic carbon in all treatment before and after digestion $(p<0.05)$. The maximum reduction of carbon content observed in $80{ }^{\circ} \mathrm{C}$ thermal treatment (exceeded by $41.8 \%$ over the control) might be due to either by being converted to cellular materials for growth and reproduction of bacteria or biogas production (Gerardi, 2003). As reported by Abdel-Hadi and 
El-Azeem (2008) the decrement of organic C indicates the effectiveness of degradation process during anaerobic digestion.

\subsection{Effect of Thermal Pre-treatments on TS and VS}

\section{Reduction}

As shown in (Figure 3), there was no significant difference in TS between thermal treatments before digestion even though significant difference was observed after AD. TS of the substrates pre-treated by $60^{\circ} \mathrm{C}$ and $80^{\circ} \mathrm{C}$ temperature following digestion were significantly lower than the control $\left(22^{\circ} \mathrm{C}\right)$, although there was no significant difference between $60^{\circ} \mathrm{C}$ and $80^{\circ} \mathrm{C}$ pre-treatments (Figure 3). This reflects that increment of temperature of pre-treatment may reduce the TS value of substrate after $\mathrm{AD}$ and result in increased biogas production. TS was significantly reduced within each thermal treatment after digestion. This decrement in TS demonstrates that a large fraction of the substrates was broken down and digested. During anaerobic digestion, the TS of the substrate decreased due to its consumption for biogas production (Gerardi, 2003).

The initial value of TS showed that the moisture content of the substrates to be only $76.2 \%$. Since studies on the most favourable percentage of total solids for biogas productions suggest $8 \%$ as the optimum TS, the initial moisture content of substrates used for this study was not optimal for wet anaerobic digestion process (Tchobanoglouset al., 1993). Therefore, $119.75 \mathrm{~mL}(100 \mathrm{~mL}$ inoculum $+19.75 \mathrm{~mL}$ distilled water) is required to bring the total solids percentage to $8 \%$.

There was no significant difference between temperature treatments in VS before AD. However, significant difference was measured in VS between treatments after $\mathrm{AD}$ (Figure 6). That is, VS of the substrates pre-treated by 60 and $80^{\circ} \mathrm{C}$ temperature following $\mathrm{AD}$ was significantly lower than that of control temperature, though there was no significant difference between 60 and 80 pre-treatments (Figure 4). Percentage reduction of VS for control, $60{ }^{\circ} \mathrm{C}$ and $80{ }^{\circ} \mathrm{C}$ pre-treated feed stocks were $28.2 \%, 61.1 \%$ and $64.3 \%$, respectively. The observed volatile solid reduction could be due to an increment of soluble materials (Ferrer $e t$ al., 2008), due to thermal pre-treatment, which increases the availability of substrate for microbes during anaerobic digestion (Carrèreet al., 2009).

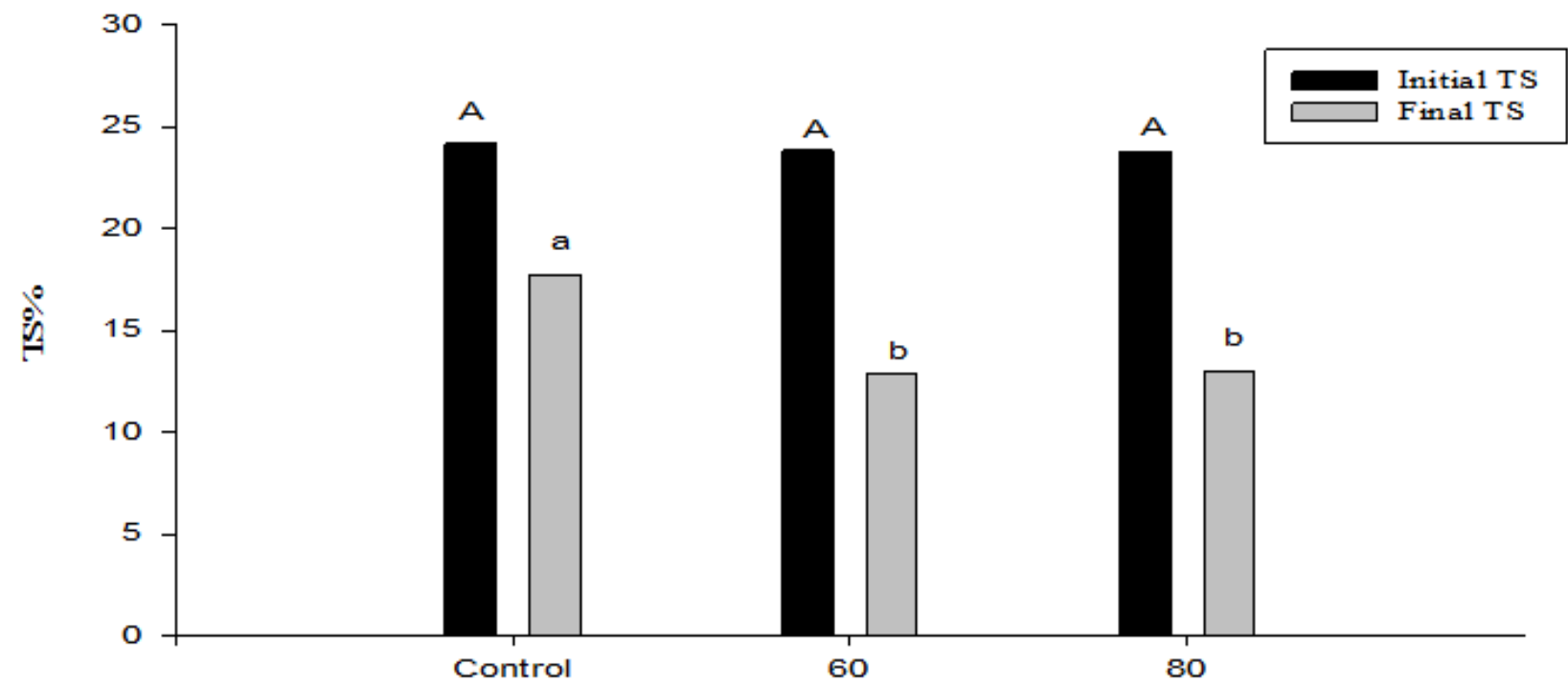

Thermal Pretreatments $\left({ }^{\circ} \mathrm{C}\right)$

Fig.3: Values of TS for thermally pre-treated substrates before and after digestion. Capital letters represent differences between $\%$ TS of the substrate under different temperature pre-treatments before digestion while small letters represent that of after digestion. Bar graphs with the same capital or small letters are not significantly different, whereas those with different capital or small letters are significantly different. TS=Total Solids. 


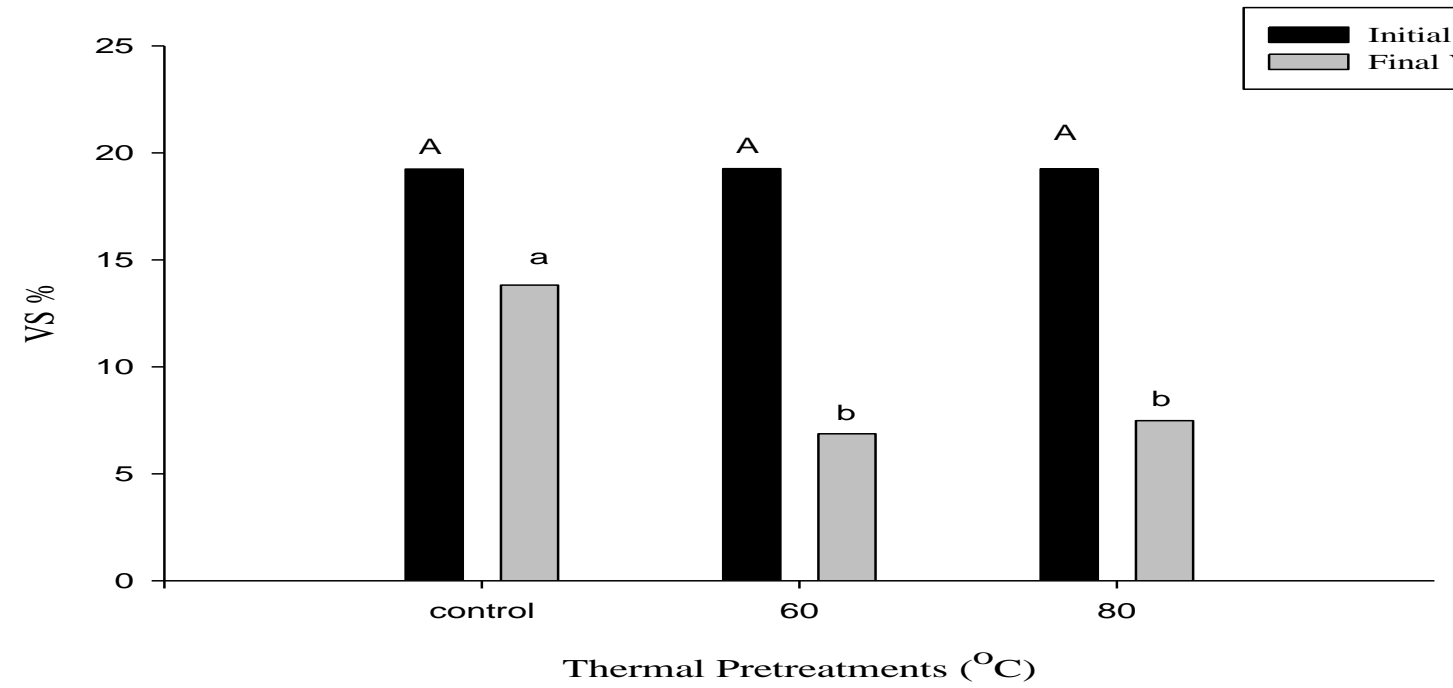

Fig.4: Values of VS for thermally pre-treated substrates before and after digestion. Capital letters represent differences between $\% V S$ of the substrate under different temperature pre-treatments before digestion while small letters represent that of after digestion. Bar graphs with the same capital or small letters are not significantly different, whereas those with different capital or small letters are significantly different. VS=Volatile Solids.

\subsection{Biogas Production from Thermally Pre-treated} Substrates

The average biogas production of control and $60^{\circ} \mathrm{C}$ was almost closer to each other at day 1 and 2 even though the production was higher in case of the substrate pre-treated by $80^{\circ} \mathrm{C}$ (Figure 5). After day 3 production of biogas from control was less than those obtained from both thermally pre-treated substrates. This illustrates that the substrate treated by $80^{\circ} \mathrm{C}$ is easily digestible by bacteria that take part in anaerobic digestion particularly hydrolytic bacteria at the early stage of the digestion. The production of gas gradually decreased from day 1 to day 17 and completely stopped starting from day 18 in all digesters containing thermally pre-treated substrate. Thus, pre-treatment does not only yield greater amount of biogas, but it also reduces hydraulic retention time needed for $\mathrm{AD}$ (Ferrer et al., 2008).

For thermally $\left(60\right.$ and $\left.80^{\circ} \mathrm{C}\right)$ pre-treated samples more than $50 \%$ of biogas were measured within 5 days. This indicates that availability of more easily degradable organic materials for microbes within this short period of time. The increased initial biogas production is credited to the increased accessibility and degradability of substrate (Rafiqueet al., 2010).

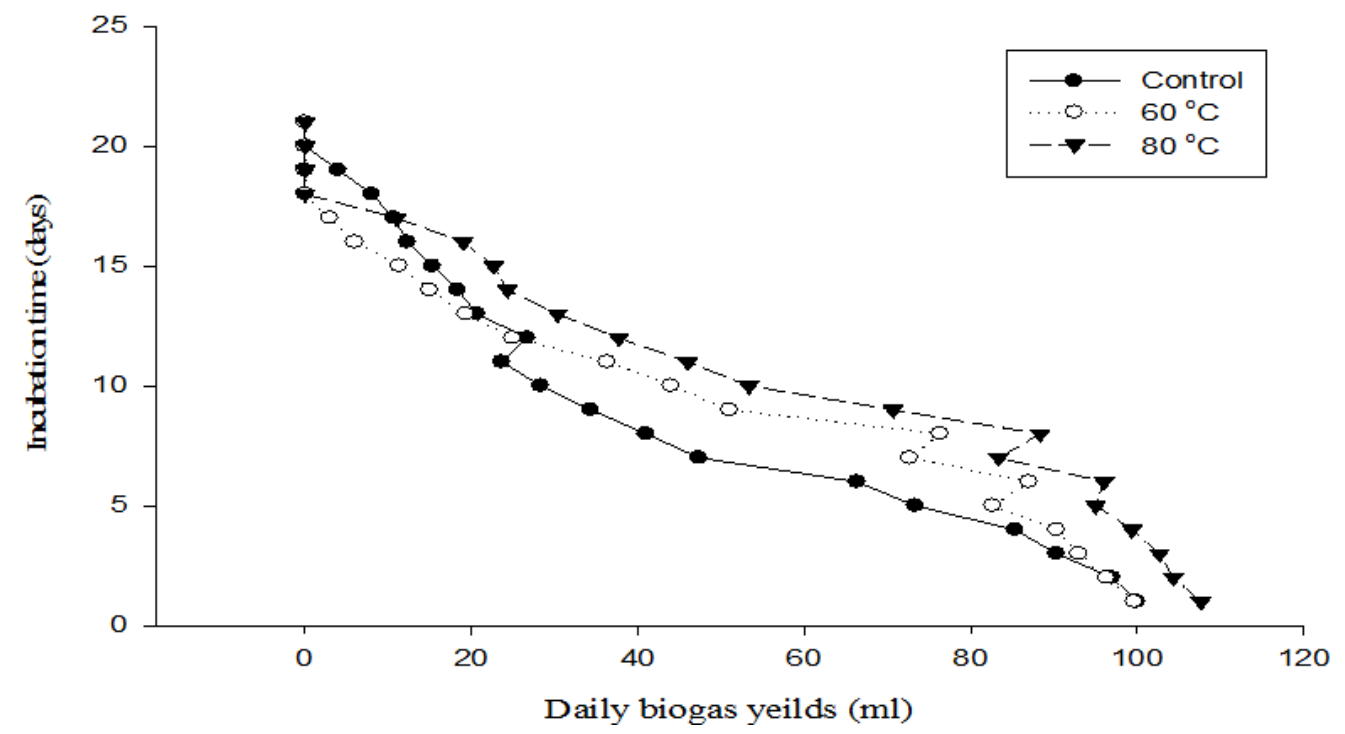

Fig.5: Daily mean biogas yield profile during batch fermentation of thermally pre-treated substrates. 
Substrates pre-treated with 60 or $80{ }^{\circ} \mathrm{C}$ significantly increased cumulative biogas yield when compared with the control temperature $(P<0.05$, Figure 6$)$. The result also revealed that there was significant difference between 60 and $80{ }^{\circ} \mathrm{C}$ treated substrate in cumulative biogas yield $(P<0.05)$. Maximum cumulative gas production was measured for $80{ }^{\circ} \mathrm{C}$ pre-treated substrate. It was exceeded by $11.7 \%$ over the control and $6.6 \%$ over $60{ }^{\circ} \mathrm{C}$ pre-treated sample.

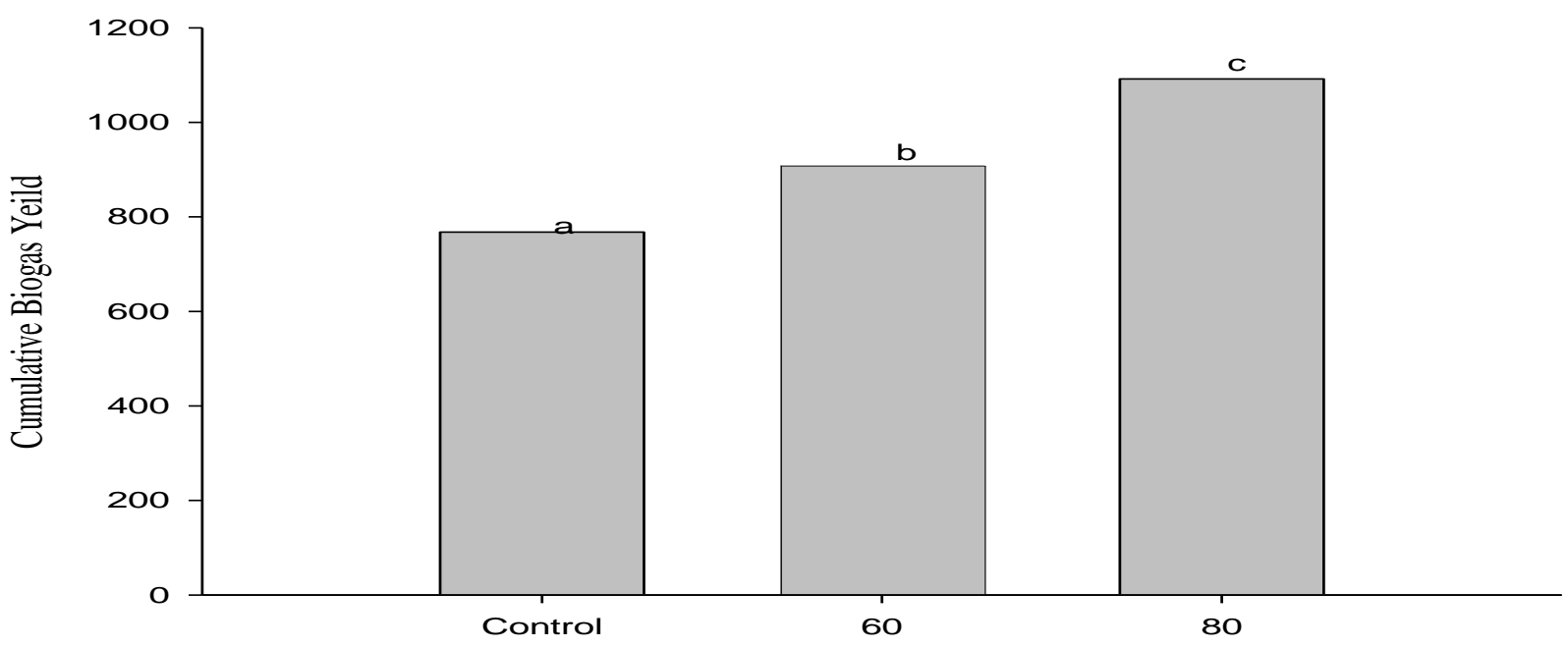

Thermal Pretreatemnts $\left(\underline{\mathrm{O}}_{\mathrm{c}}\right)$

Fig.6: Cumulative biogas yield of the different level of thermally pre-treated substrates (means with the same letter are not significantly different.

\subsection{Analysis of $\mathbf{p H}$ and \% $\mathrm{C}$ of Alkali Pre-treated Substrate}

Table.4: Characteristics of blended PM and OP at 75\%: 25\% ratio for chemical pre-treatment before and after AD (values are mean $\pm S E, n=3$ ).

\begin{tabular}{|c|c|c|c|c|}
\hline \multirow[b]{2}{*}{ Amount of $\mathrm{CaO}(\mathrm{g})$} & \multicolumn{4}{|l|}{ Parameters } \\
\hline & Initial $\mathrm{pH}$ & Final pH & $\%$ initial organic $\mathrm{C}$ & $\%$ final organic $\mathrm{C}$ \\
\hline 0 (Control) & $6.82 \pm 0.01^{\mathrm{bC}}$ & $8.45 \pm 0.01^{\mathrm{aA}}$ & $10.69 \pm 0.01^{\mathrm{aA}}$ & $7.68 \pm 0.01^{\mathrm{bA}}$ \\
\hline 0.5 & $7.49 \pm 0.01^{\mathrm{bB}}$ & $8.12 \pm 0.03^{\mathrm{aA}}$ & $10.6 \pm 0.01^{\mathrm{aA}}$ & $4.93 \pm 0.34^{\mathrm{bB}}$ \\
\hline 1.5 & $7.51 \pm 0.01^{\mathrm{bB}}$ & $8.46 \pm 0.01^{\mathrm{aA}}$ & $10.59 \pm 0.01^{\mathrm{aA}}$ & $4.02 \pm 0.32^{\mathrm{bC}}$ \\
\hline 2.5 & $07.54 \pm 0.00^{\mathrm{bA}}$ & $8.45 \pm 0.02^{\mathrm{aA}}$ & $10.57 \pm 0.01^{\mathrm{aA}}$ & $2.98 \pm 0.01^{\mathrm{bD}}$ \\
\hline
\end{tabular}

Means followed by different small letters in row are significant at 0.05 probability levels for paired samples $\mathrm{T}$ test within treatment. Means followed by different capital letter in column are significantly different at 5\% level of significance between treatments.

The initial $\mathrm{pH}$ value of all the substrate was in the range of $6.82 \pm 0.01$ to $7.54 \pm 0.05$, which is ideal for anaerobic digestion (Thy et al., 2003). Samples treated with $\mathrm{CaO}$ were buffered by $6 \mathrm{H}_{2} \mathrm{SO}_{4}$ in order to keep the $\mathrm{pH}$ of the digester around neutral. This speeds up the activity of microbes which were involved in $\mathrm{AD}$ as they are sensitive to $\mathrm{pH}$. After digestion, no significant difference was observed between the treatments, and all of them were existed within the range of alkaline $\mathrm{pH}$. This may be attributed to the formation of $\left(\mathrm{NH}_{4}\right)_{2} \mathrm{CO}_{3}$ after digestion
(Georgacakiset al., 1982) (Table 4). Significant \%C variation was observed before digestion between control and chemically treated substrates even though no significant difference was seen among chemically treated substrates. In all treatments significant difference in \%C was observed after $\mathrm{AD} \quad(\mathrm{p}<0.05$ Table, 4.4). Percentage of carbon degradation of control, $0.5 \mathrm{~g} \mathrm{CaO}, 1.5 \mathrm{~g} \mathrm{CaO}$ and $2.5 \mathrm{~g} \mathrm{CaO}$ were $28 \%, 53 \%, 62 \%$ and $71 \%$, respectively. This indicates that degradation of organic carbon increased with increment of Cao concentration to some extent. The increase in the $\mathrm{C}$ degradation demonstrates the effectiveness of digestion process for pre-treated substrate as organic carbon is removed in anaerobic digesters through its conversion either into gas or cellular materials (Abdel-Hadi and El-Azeem, 2008). 
3.8. Analysis of Total Solids and Volatile Solids

Reduction.

Before $\mathrm{AD}$, no significant difference was seen among chemically treated substrates in TS, and between chemically treated substrate and the control. However, variation was noticed in all treatments after digestion (Figure 7). The amount of TS was slightly decreased as concentration of $\mathrm{CaO}$ from 0 to $2.5 \mathrm{~g}$. This shows that amount of $\mathrm{CaO}$ added to the substrate affects TS value of the substrate. Percentage reduction of TS of a control, and the samples treated by $0.5 \mathrm{~g}, 1.5 \mathrm{~g}$ and $2.5 \mathrm{~g}$ of $\mathrm{CaO}$ were $25.48 \%$, and $28.9 \%$, $36.35 \%$ and $44.66 \%$, respectively. That is, \% TS of the substrates treated with the highest amount of $\mathrm{CaO}$ was significantly lower than all the other treatments after AD. Comparison of TS for each chemical treatment between before and after digestion showed that TS was significantly reduced after digestion due to its consumption to biogas (Gerardi, 2003).

Initially, the percentage total solids of the substrate show that the moisture content of the substrate to be only $76.2 \%$.

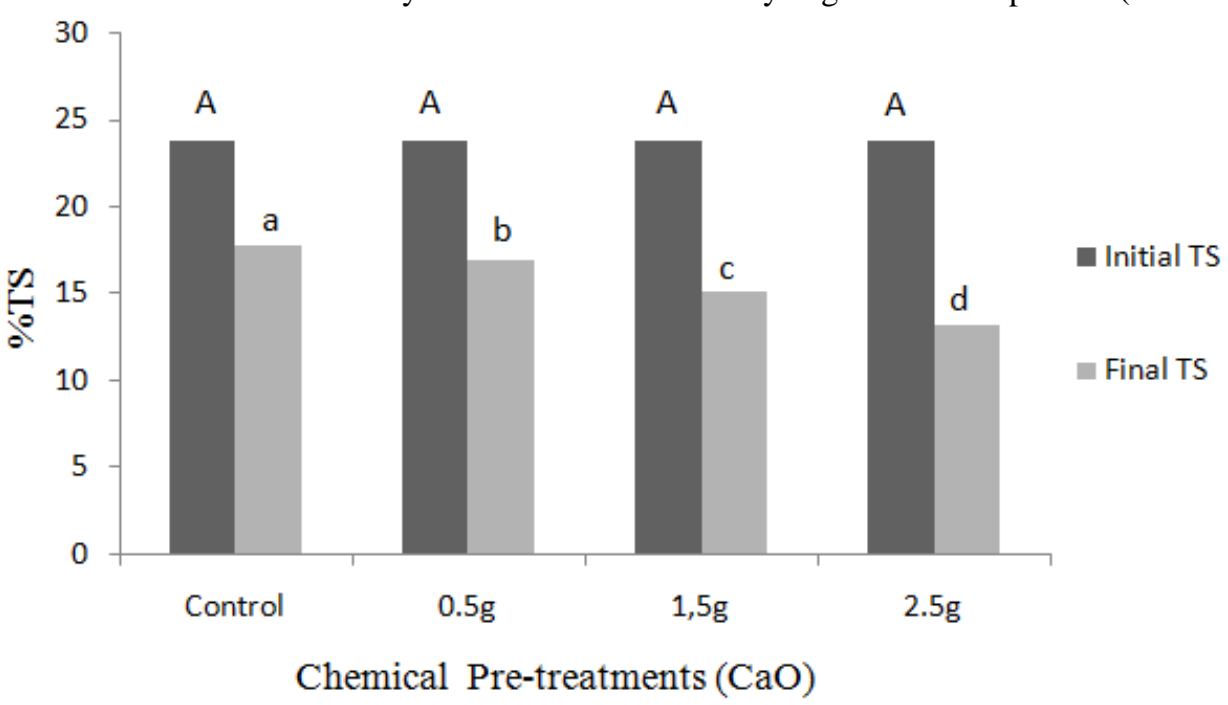

Fig.7: Values of TS for CaO pre-treated substrates before and after digestion. Capital letters represent differences between \%TS of the substrate under different chemical pre-treatments before digestion while small letters represent that of after digestion. Bar graphs with the same capital or small letters are not significantly different, whereas those with different capital or small letters aresignificantly different. $T S=$ Total Solids 


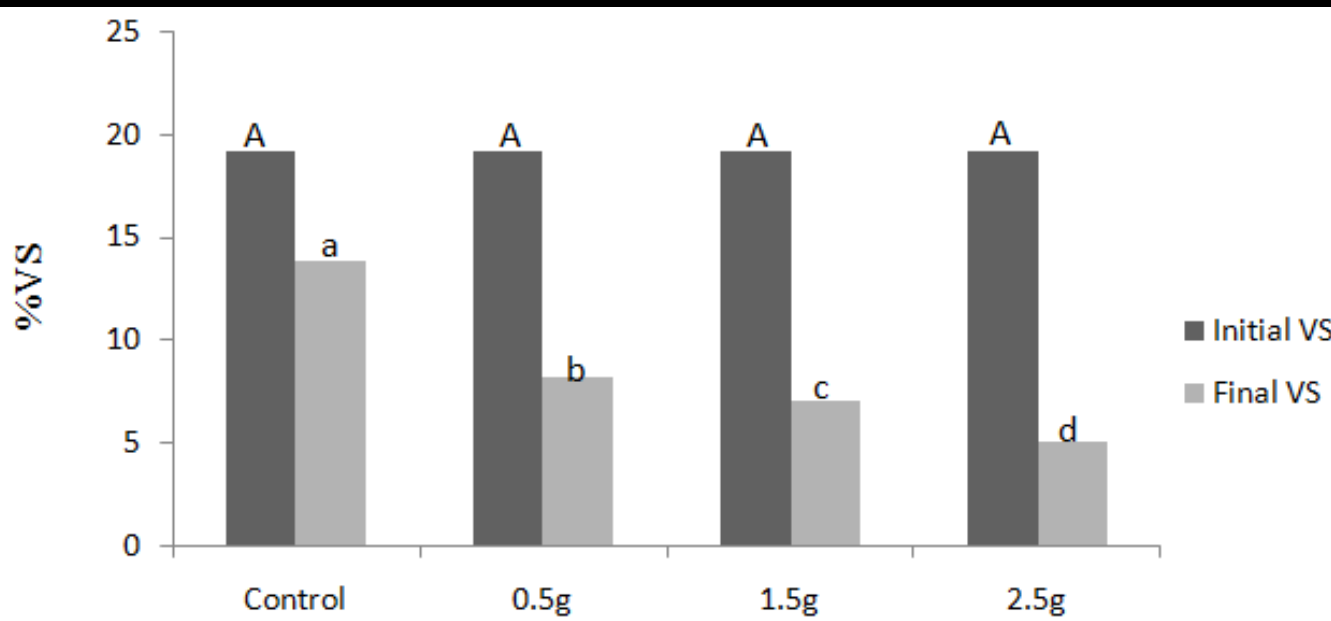

\section{Chemical Pre-treatments $(\mathrm{CaO})$}

Fig.8: Values of VS for CaO pre-treated substrates before and after digestion. Capital letters represent differences between \%VS of the substrate under different chemical pre-treatments before digestion while small letters represent that of after digestion. Bar graphs with the same capital or small letters are not significantly different, whereas those with different capital or small letters are significantly different. VS=Volatile solids

\subsection{Biogas Production of Alkali Pre-treated substrates}

Biogas produced from all digesters was recorded from day 1 to day 21 (Appendix table 3). Gas production from a substrate treated by $1.5 \mathrm{~g}$ and $2.5 \mathrm{~g}$ of $\mathrm{CaO}$ was 0 until the second day. This could be due to the addition of $6 \mathrm{~N} \mathrm{H}_{2} \mathrm{SO}_{4}$ to maintain the $\mathrm{pH}$ at neutral. Addition of sulphuric acid results in by-products such as 5-hydroxylmethylfurfural (5HMF)and furfural (Larsson et al., 1999). Though these byproducts do not inhibit methane production from xylose (Barakatet al., 2012), the methanogenic microorganisms require a period of adaptation to start methane production.
In a substrate which received $0.5 \mathrm{~g}$ of $\mathrm{CaO}$, gas production was started at day 2 because of low concentration of $\mathrm{CaO}$, and this might not affect the activity of microbes. Maximum production of gas was observed at day 4 from all chemically pre-treated samples as microbes effectively degrade the substrate. After day 4, production of gas from chemically subjected substrates was slightly decreased and finally ceased at day 18 although some fluctuations were noticed a few days (Figure 9). This could be attributed to scarcity of the necessary nutrients from the digesters (Hansen et al., 1998).

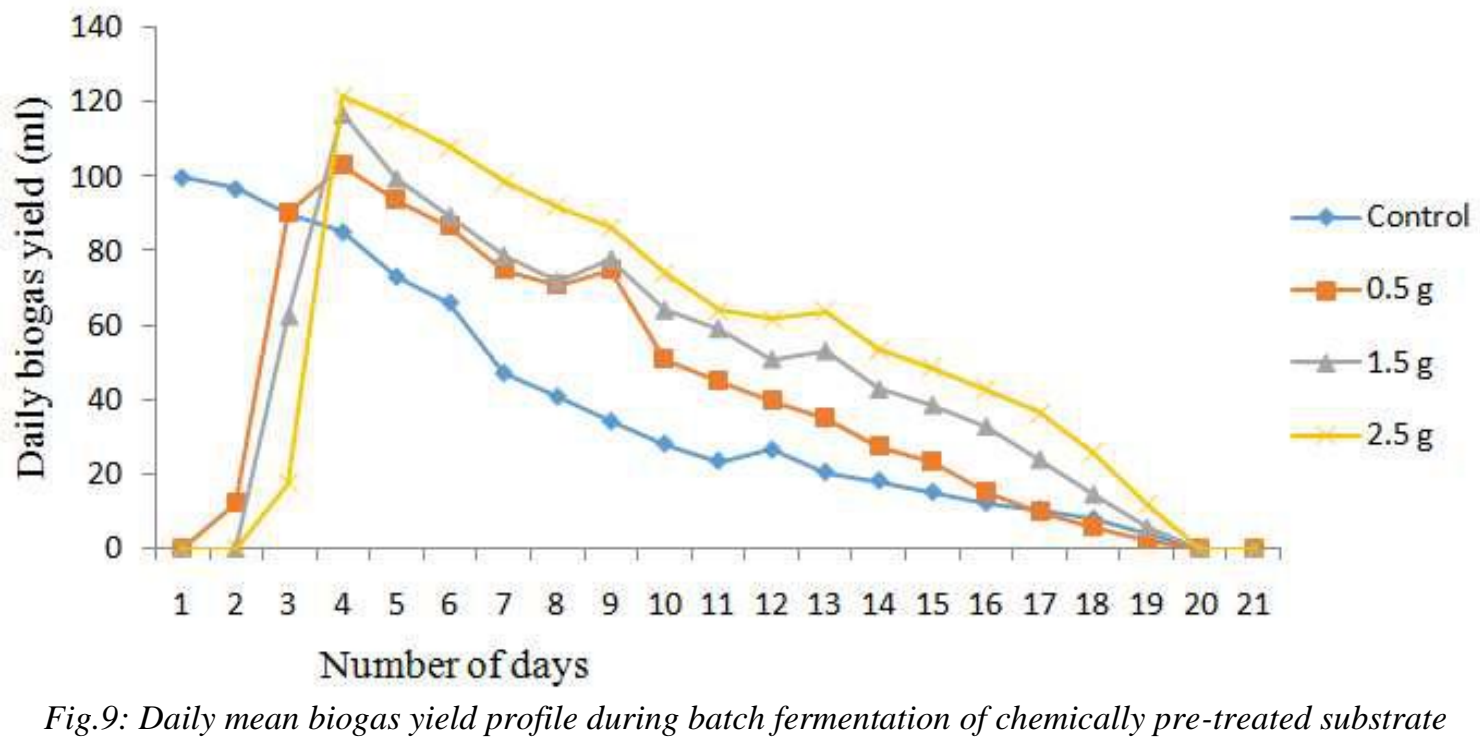


Among all treatments, significant difference in gas production was noticed even though high variation was not observed between control and a sample treated by $0.5 \mathrm{~g}$ of $\mathrm{CaO}$ (Figure 10). The highest cumulative biogas production was obtained from a substrate treated by $2.5 \mathrm{~g} \mathrm{CaO}$ which exceed by 139,250 and 356 over $1.5 \mathrm{~g} \mathrm{CaO}, 0.5 \mathrm{~g} \mathrm{CaO}$ and control, respectively. Compared to the other chemically treated substrates, the lowest gas yield was obtained from a sample treated with $0.5 \mathrm{~g}$ of $\mathrm{CaO}$.

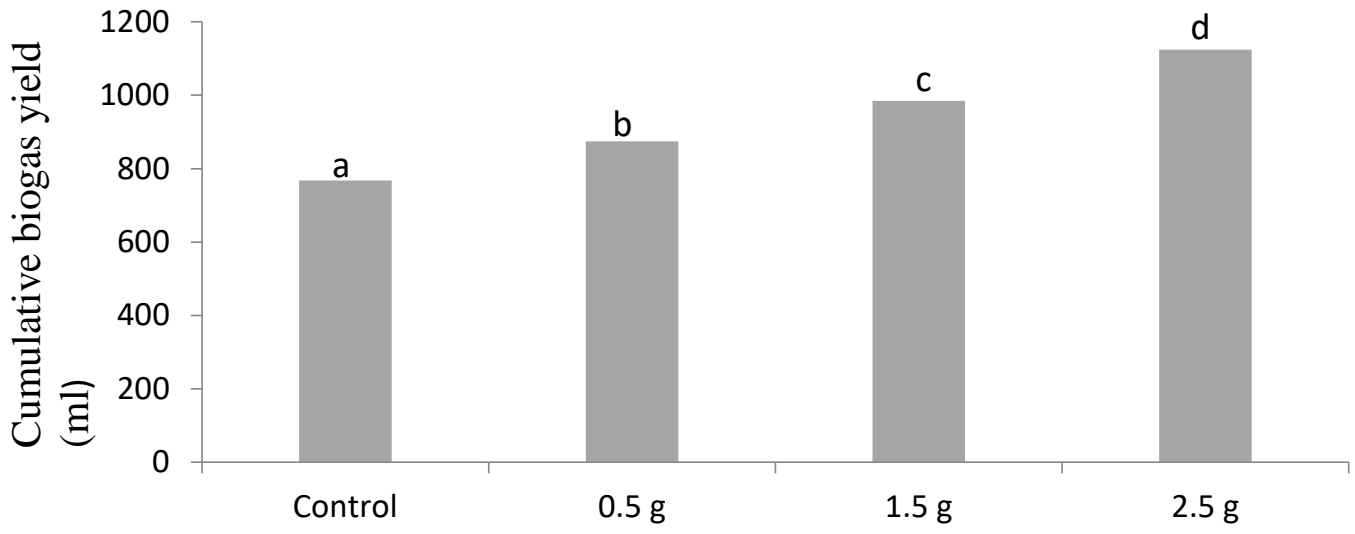

Chemical Pre-treatments $(\mathrm{CaO})$

Fig.10: Cumulative biogas yield for the different level of CaO pre-treatments (means with the same letter are not significantly different).

\section{SUMMARY, CONCLUSIONS AND RECOMMENDATIONS}

\subsection{Summary and Conclusions}

The main aim of the study was to produce biogas from cofermentation of poultry manure and orange peel at different mix ratio which took place under a series of experiments at mesophilic condition. This series of experiments were taken place within 21 days. Anaerobic digestibility tests were carried out to get appropriate mix ratio for maximum biogas production from wet co-digestion of $\mathrm{PM}$ and $\mathrm{OP}$ at 5 different proportions. During the first phase of experiments, the mix ratio of $75 \% \mathrm{PM}+25 \% \mathrm{OP}$ resulted highest biogas yield compared to the rests, and selected for second phase of experiment. Then $75 \% \mathrm{PM}+25 \% \mathrm{OP}$ was pre-treated with temperature of $60^{\circ} \mathrm{C}$ and $80^{\circ} \mathrm{C}$ and different concentrations of $\mathrm{CaO}(0.5 \mathrm{~g}, 1.5 \mathrm{~g}$ and $2.5 \mathrm{~g})$ in order to identify the effect of pre-treatments on biogas production.

Thermal pre-treatments were carried out by treating the selected best performing substrate $(75 \% \mathrm{PM}+25 \% \mathrm{OP})$ with temperature of $60^{\circ} \mathrm{C}$ and $80^{\circ} \mathrm{C}$. Maximum production of biogas was obtained from a mix ratio treated by $80^{\circ} \mathrm{C}$ compared to control and a sample treated by $60^{\circ} \mathrm{C}$. Cumulative biogas production from a sample treated with $80^{\circ} \mathrm{C}$ was $1091.67 \mathrm{ml}$, while it was $768 \mathrm{ml}$ and $909 \mathrm{ml}$ from control and a substrate treated by $60^{\circ} \mathrm{C}$ respectively. Maximum reduction of TS and VS, and high degradation of organic carbon was noticed in a mix ratio subjected by $80^{\circ} \mathrm{C}$. Chemical pre-treatment was done by treating $75 \% \mathrm{PM}+25 \% \mathrm{OP}$ mix ratio with different amount of $\mathrm{CaO}$ $(0.5 \mathrm{~g}, 1.5 \mathrm{~g}$ and $2.5 \mathrm{~g})$. It was noticed that cumulative biogas yield from $\mathrm{CaO}$ pre-treated substrate increase gradually with gram of amount of $\mathrm{CaO}$ added, indicating that more organic material was available for microbes for degradation. Significant difference of gas production was observed between the treatments $(\mathrm{p}>0.05)$. The maximum production of biogas $(1124 \mathrm{ml})$ was obtained from a sample pre-treated by $2.5 \mathrm{~g}$ of $\mathrm{CaO}$. This may be due to the increment of degradability of substrate after pre-treatments. This in turn leads to high availability of nutrients for microbes, and finally improves biogas production. Generally, pretreatments modify biogas production from different feed stocks as they speed up the activity of microbes.

\subsection{Recommendations}

Based on the finding of the study, the following recommendations are given;

$\checkmark$ Ranking of mix ratios should be done based on reduction of TS, VS, organic Carbon, and producing the highest biogas yield in order to select a mix ratio for Thermal and Alkali pretreatments.

$\checkmark$ Other combination effective pre-treatments could be used to identify the most relevant one which improve the production of gas without eradicating the nutrients of the feed stocks, and initiating the activity of microbes.

$\checkmark \quad$ The five mix ratios could be characterized based on organic loading rate, Carbon/Nitrogen ratio and Carbon/ Phosphorous ratio to assess their effect on biogas production. 
$\checkmark$ Orange peel should be pre-treated by appropriate pre-treatments to reduce the inhibitory effects and optimize biogas production.

\section{REFERENCES}

[1] Abdel-Hadi, M.A. and S.A.M. Abd El-Azeem, 2008. Effect of heating, mixing and digester type on biogas production from buffalo dung. Misr J. Agricultural Engineering 25(4): 1454-1477.

[2] Abuabaker, B. and N. Ismail, 2012. Anaerobic Digestion of Cow Dung for Biogas Production. ARPN Journal of Engineering and Applied Science 7 (2):169172.

[3] Ahn, H., M. Smith, S. Kondrad and J. White, 2009. Evaluation of biogas production potentialby dry anaerobic digestion of switch grass-animal manure mixtures. Applied Biochemistry and Biotechnology 160:965-975

[4] Angelidaki, I. and B.K. Ahring. 1999. Methods for increasing the biogas potential from the recalcitrant organic matter contained in manure. pp. 23-32. International Journal ofMata-Alvarez, A.Tilche and F. Cecchi (eds). Proceedings of the Second International Symposium on Anaerobic Digestion of Solid Wastes. Barcelona, Spain.

[5] APHA (American Public Health Association). 1999. Standardmethods for examinations of water and wastewater, 19th Edition. American Public Health Association, Washington DC, USA.

[6] Arogo, J.O., Z. Wen, J. Ignosh, E. Bendfeldt and E.R. Collins. 2009. Biomethane Technology. College of Agriculture and Life Sciences, Virginia Polytechnic Institute and State University, publication 442-881.

[7] Barakat, A., F. Monlau, J. Steyer and H. Carrere, 2012. Effect of lignin-derived and furan compounds found in lignocellulosichydrolysates on biomethane production. Bioresource Technology 104:90-99.

[8] Bisypln. 2012. The Bioenergy System Planners Handbook - BISYPLAN.

[9] (http://bisyplan.bioenarea.eu/html-files-en/02-03.html) Assessed on January 6, 2014

[10] Bonmatí, A., X. Flotats, L. Mateu and E. Campos. 2001. Study of thermal hydrolysis as a pre-treatment to mesophilic anaerobic digestion of pig slurry. Water Science Technology. 44 (4):109-116.

[11] Braun, R., P. Huber and J. Meyrath, 1981. Ammonia toxicity in liquid piggery manure digestion. Biotechnology 3:159-164.

[12] Bruni E. 2010. Improved anaerobic digestion of energy crops and agricultural residues, Department of
Environmental Engineering, Technical University of Denmark.

[13]Buysman, E., 2009. Anaerobic Digestion for Developing Countries with Cold Climates - Utilizing solar heat to address technical challenges and facilitating dissemination through the use of carbon finance. University of Wagenigen, Environmental Technology, Wagenigen.

[14] Carlsson, M., A. Lagerkvist and F. MorganSagastume, 2012. The effect of substrate pre-treatment on anaerobic digestion systems: A review. Waste Manage, 32:1634-1650.

[15] Carrère, H., B. Sialve and B. Bernet, 2009. Improving pig manure conversion into biogas by thermal and thermo-chemical pre-treatments. Bioresource Technology 100:3690-3694.

[16] Carrère H., Dumas C., Battimelli A., Batstone D.J., Delgenès J.P., Steyer J.P., Ferrer I. 2010. Pretreatment methods to improve sludge anaerobic degradability.

[17] Devlin, D.C., S.S.R. Esteves, R.M. Dinsdale and A.J. Guwy. 2011. The effect of acid pre-treatment on the anaerobic digestion and dewatering of waste activated sludge. Bioresource Technology 102:4076-4082.

[18]EREDPC (Ethiopian Rural Energy Development Promotion Centre). 2008. National Biogas Programme Ethiopia: Programme Implementat ion Document) Accessed on October 11, 2014.

[19]FAO (Food and Agricultural Organiztion). 1990. Food and Agricultural Organization of the United Nations Agrometeorology group, Remote Sensing Center Research and Technology Division. Rome, Italy.

[20]Ferrer, I., S. Ponsá, F. Vázquez and X. Font, 2008. Increasing biogas production by thermal $\left(70{ }^{\circ} \mathrm{C}\right)$ sludge pre-treatment prior to thermophilic anaerobic digestion. Biochemical Engineering 42:186-192.

[21]Forgács, G. 2012. Methane production from citrus wastes: process development and cost estimation.Biotechnology 8(7):250-255

[22] Fulford, D., 1988. Running a biogas programme, a handbook. Intermediate technology Publications, London. 123pp.

[23] Georgacakis, D., D.M. Sievers and E.L. Iannotti, 1982. Buffer stability in manure digesters. Agricultural Wastes, 4:427-441.

[24] Gerardi, M.H, 2003.The Microbiology of Anaerobic Digesters.A John Wiley and Sons. pp. 99-103

[25] GetachoDagnew. 2012. Effect of adding urea on biogas production potentials of selected fruit wastes. M.Sc. thesis, Addis Ababa University, Addis Ababa, Ethiopia. 
[26] Hansen, H.H., I. Angelidaki and B.K. Ahring, 1999. Improving thermophilic anaerobic digestion of swine manure. Water Resources, 33 (8):1805-1810.

[27]Hills, D. J. and D.W. Roberts, 1981. Anaerobic digestion of dairy manure and field crop residues. Agricultural Wastes 3:179-189.

[28] Hobson, P.N., S. Bousfield and R. Summers, 1981. Methane production from agricultural and domestic waste. Applied science publisher.

[29] Itodo, I.N, E.B. Lucas and E.I. Kucha. 1992. The effect of media materials and its quality on biogas yield. Nigerian Journal of Renewable energy 3(1):4549.

[30] Kaparaju, P., and Felby, C. 2010. Characterization of lignin during oxydative and hydrothermal pretreatment processes of wheat straw and corn stover. Bioresource Technology 101:3175-3181.

[31] Kapraju, N. and Rintala, A. 2006. Thermophilic anaerobic digestion of industrial orange waste. Environmental Technology 27:623-633.

[32] Karekezi, S. 1994. Disseminating renewable energy technologies in sub-Saharan Africa. Annual Reviews 19:387-421.

[33] Khanal S.K. 2008. Anaerobic biotechnology for bioenergy production, John Wiley and Sons.

[34] Lawrence, M. 2012. Global biogas market to nearly double in size to $\$ 33$ billion by 2022 .

[35] Li, X., L.Q. Li, M.X. Zheng, G.Z. Fu and J.S. Lar, 2009. Anaerobic co-digestion of cattle manure with corn stover pre-treated by sodium hydroxide for efficient biogas production. Energy Fuels 23:46354639.

[36] Lo NieeLiew, B.S. 2011. Solid state anaerobic digestion of lignocellulosic biomass for biogas production. (Unpublished MSc thesis), presented to the School of Graduate Studies of the Ohio State University. 44pp.

[37]Lo'pez Torres, M. and M.D.C. Espinosa Llorens, 2008. Effect of alkaline pre-treatment on anaerobic digestion of solid wastes. Waste Manage28:22292234.

[38] Macias-Corral, M., Z. Samani, A. Hanson, G. Smith, P. Funk, H. Yu and J. Longworth, 2008. Anaerobic digestion of municipal solid waste and agricultural waste and the effect of co-digestion with dairy cow dung. Bioresoure Technology 99:8288-8293.

[39] Mizuki, E. 1990. Inhibitory Effect of citrus peel on anaerobic digestion. Biological Wastes33:161-168.
[40] Mladenovska, Z., H. Hartmann, T. Kvist, M. SalesCruz, R. Gani and B.K. Ahring. 2006 Thermal pretreatment of the solid fraction of manure: impact on the biogas reactor performance and microbial community. Water Science Technology, 53 (8):59-67.

[41] Rafique R., Poulsen T.G., Nizami A.S., Asam Z.Z., Murphy J.D. and Kiely G. 2010. Effect of thermal, chemical and thermo-chemical pre-treatments to enhance methane production. ThermalEnergy, 35:4556-4561.

[42] Sunarso, S., Z. Johari, I.N. Widiasa and Budiyono.2012. The effect of feed to inoculums ration biogas production rate from cattle manure using rumen fluid as inoculums International Journal Waste resource. 2 (1):1-4.

[43] TamiratAragaw. 2012. The effect of co-digestion of cattle manure with organic kitchen waste using rumen fluid as inoculum on the rate and amount of biogas production. M.Sc. Thesis, Haramaya University, Haramaya, Ethiopia.

[44] Tchobanoglous, G., H. Theisen and S. Vigil. 1993. Integrated Solid Waste Management Engineering: Principle and Management Issues, McGraw-Hill U.S, Singapore

[45] Thy, S., T.R. Preston and J. Ly, 2003. Effect of retention time on gas production and fertilizer value of biodigester effluent. Rural Development 15(7):1-24

[46] Ward A.J., Hobbs P.J., Holliman P.J. and Jones D.L. 2008. Optimization of the anaerobic digestion of agricultural resources. Bioresource Technology, 99:7928-7940.

[47] Yadvika, Santosh, Sreekrishnan, T.R., Kohli, S. and Rana, V. 2004. Enhancement of biogas production from solid substrates using different techniques, a review.

[48] Yeole, T.Y. and D.R. Ranande, 1992. Alternative feedstock for Biogas. Tropical Animal production 9(3):10-16.

[49] Yitayal Addis. 2011. Study on biogas energy production from leaves of Justiciaschimperiana.M.Sc.Tthesis, Addis Ababa University, Addis Ababa, Ethiopia.

[50]Zhong, W., Zhang, Z., Qiao, W. and Liu M. 2011. Comparison of chemical and biological pretreatment of corn straw for biogas production by anaerobic digestion. Renewable Energy, 36:1875-1879. 


\section{APPENDICES}

Appendix Table 1. Daily mean biogas yields from co-digestion $\pm \mathrm{SE}(\mathrm{mL})(\mathrm{n}=3)$

\begin{tabular}{|c|c|c|c|c|c|}
\hline \multirow[b]{2}{*}{ Days } & \multicolumn{5}{|l|}{ Mix ratio } \\
\hline & $100 \% \mathrm{PM}$ & $75 \% \mathrm{PM}+25 \% \mathrm{OP}$ & $50 \% \mathrm{PM}+50 \% \mathrm{OP}$ & $25 \% \mathrm{PM}+75 \% \mathrm{OP}$ & $100 \% \mathrm{OP}$ \\
\hline 1 & $95.33 \pm 0.88$ & $100 \pm 1.15$ & $77 \pm 1.15$ & $48.33 \pm 1.20$ & $34.67 \pm 1.20$ \\
\hline 2 & $87.33 \pm 0.88$ & $97 \pm 1.15$ & $68.33 \pm 0.88$ & $42 \pm 1.15$ & $31 \pm 0.57$ \\
\hline 3 & $77.67 \pm 1.45$ & $90.33 \pm 0.88$ & $60.33 \pm 1.20$ & $34 \pm 1.15$ & $26.67 \pm 0.88$ \\
\hline 4 & $67.67 \pm 1.86$ & $85.33 \pm 0.88$ & $51.67 \pm 0.67$ & $28 \pm 1.15$ & $20.67 \pm 1.86$ \\
\hline 5 & $56.33 \pm 1.86$ & $73.33 \pm 1.45$ & $45.33 \pm 0.88$ & $25.33 \pm 0.88$ & $18 \pm 1.53$ \\
\hline 6 & $48.67 \pm 1.20$ & $66.33 \pm 1.45$ & $40.33 \pm 0.33$ & $23 \pm 0.58$ & $16.67 \pm 0.88$ \\
\hline 7 & $39.33 \pm 1.45$ & $47.33 \pm 1.20$ & $38 \pm 0.58$ & $20 \pm 1.00$ & $14.33 \pm 0.88$ \\
\hline 8 & $34.67 \pm 0.88$ & $41 \pm 1.15$ & $33.33 \pm 0.33$ & $17.33 \pm 1.76$ & $13.00 \pm 1.53$ \\
\hline 9 & $32 \pm 1.15$ & $34.33 \pm 1.76$ & $29 \pm 1.15$ & $14.33 \pm 1.20$ & $11.33 \pm 0.88$ \\
\hline 10 & $26 \pm 1.16$ & $28.33 \pm 0.67$ & $25.67 \pm 1.76$ & $11.33 \pm 0.88$ & $8.33 \pm 0.88$ \\
\hline 11 & $23.33 \pm 1.20$ & $23.67 \pm 0.88$ & $18.67 \pm 2.01$ & $11 \pm 1.15$ & $5 \pm 0.58$ \\
\hline 12 & $25 \pm 1.15$ & $26.67 \pm 1.45$ & $21 \pm 1.73$ & $12.67 \pm 0.88$ & $6.33 \pm 0.88$ \\
\hline 13 & $17.67 \pm 1.20$ & $20.67 \pm 0.88$ & $13.33 \pm 1.20$ & $10.33 \pm 0.33$ & $4 \pm 0.58$ \\
\hline 14 & $14 \pm 0.58$ & $18.33 \pm 0.88$ & $10.67 \pm 0.88$ & $8 \pm 1.73$ & $3.33 \pm 0.67$ \\
\hline 15 & $12 \pm 1.15$ & $15.33 \pm 0.88$ & $8.67 \pm 0.67$ & $7 \pm 1.15$ & $2 \pm 0.58$ \\
\hline 16 & $11 \pm 1.15$ & $12.33 \pm 1.33$ & $7.33 \pm 0.88$ & $6 \pm 0.58$ & $0.67 \pm 0.33$ \\
\hline 17 & $8.33 \pm 0.88$ & $10.67 \pm 1.20$ & $5.33 \pm 0.88$ & $5.67 \pm 0.33$ & $0 \pm 0$ \\
\hline 18 & $6.33 \pm 0.88$ & $8 \pm 0.58$ & $3.67 \pm 0.33$ & $3.67 \pm 1.33$ & $0 \pm 0$ \\
\hline 19 & $2 \pm 0.58$ & $4 \pm 0.58$ & $2 \pm 1.15$ & $1.33 \pm 0.88$ & $0 \pm 0$ \\
\hline 20 & $0 \pm 0$ & $0 \pm 0$ & $0 \pm 0$ & $0 \pm 0$ & $0 \pm 0$ \\
\hline 21 & $0 \pm 0$ & $0 \pm 0$ & $0 \pm 0$ & $0 \pm 0$ & $0 \pm 0$ \\
\hline Total & 659.33 & 768 & 601 & 328 & 218.33 \\
\hline
\end{tabular}

Appendix Table 2. Daily mean biogas yields from thermal pre-treatment test $\pm S E(m L)(n=3)$

\begin{tabular}{llll}
\hline \multicolumn{3}{l}{ Thermal Pre-treatment } & \\
Days & Control & $60{ }^{\circ} \mathrm{C}$ & $80^{\circ} \mathrm{C}$ \\
\hline 1 & $100 \pm 1.15$ & $99.67 \pm 0.88$ & $107.67 \pm 1.45$ \\
2 & $97 \pm 1.15$ & $96.33 \pm 0.33$ & $104.33 \pm 0.88$ \\
3 & $90.33 \pm 0.88$ & $93 \pm 1.53$ & $102.67 \pm 1.20$ \\
4 & $85.33 \pm 0.88$ & $90.33 \pm 1.20$ & $99.33 \pm 0.67$ \\
5 & $73.33 \pm 1.45$ & $82.67 \pm 1.45$ & $95 \pm 1.15$ \\
6 & $66.33 \pm 1.45$ & $87 \pm 1.53$ & $96 \pm 0.58$ \\
7 & $47.33 \pm 1.20$ & $72.67 \pm 0.67$ & $83.33 \pm 0.67$ \\
8 & $41 \pm 1.15$ & $76.33 \pm 0.67$ & $88.33 \pm 0.88$ \\
9 & $34.33 \pm 1.76$ & $51 \pm 1.15$ & $70.67 \pm 0.88$ \\
10 & $28.33 \pm 0.67$ & $44 \pm 1.73$ & $53.33 \pm 1.20$ \\
11 & $23.67 \pm 0.88$ & $36.33 \pm 1.45$ & $46 \pm 1.15$ \\
12 & $26.67 \pm 1.45$ & $25 \pm 0.58$ & $37.67 \pm 1.45$ \\
13 & $20.67 \pm 0.88$ & $19.33 \pm 0.88$ & $30.33 \pm 1.33$ \\
14 & $18.33 \pm 0.88$ & $15 \pm 0.58$ & $24.33 \pm 1.20$ \\
15 & $15.33 \pm 0.88$ & $11.33 \pm 0.88$ & $22.67 \pm 1.45$ \\
16 & $12.33 \pm 1.33$ & $6 \pm 0.58$ & $19 \pm 1.16$
\end{tabular}




\begin{tabular}{llll}
17 & $10.67 \pm 1.20$ & $3 \pm 0.58$ & $11 \pm 1.15$ \\
18 & $8 \pm 0.58$ & $0 \pm 0$ & $0 \pm 0$ \\
19 & $4 \pm 0.58$ & $0 \pm 0$ & $0 \pm 0$ \\
20 & $0 \pm 0$ & $0 \pm 0$ & $0 \pm 0$ \\
21 & $0 \pm 0$ & $0 \pm 0$ & $0 \pm 0$ \\
Total & 768 & 909 & 1091.67 \\
\hline
\end{tabular}

Appendix Table 3. Daily mean biogas yield from $\mathrm{CaO}$ pre-treatment test $\pm \mathrm{SE}(\mathrm{ml})(\mathrm{n}=3)$

\begin{tabular}{lllll}
\hline \multicolumn{5}{l}{ Chemical pre-treatment $(\mathrm{CaO})$} \\
Days & Control & $0.5 \mathrm{~g}$ & $1.5 \mathrm{~g}$ & $2.5 \mathrm{~g}$ \\
\hline 1 & $100 \pm 1.15$ & $0 \pm 0$ & $0 \pm 0$ & $0 \pm 0$ \\
2 & $97 \pm 1.15$ & $12.33 \pm 1.45$ & $0 \pm 0$ & $0 \pm 0$ \\
3 & $90.33 \pm 0.88$ & $90.67 \pm 1.20$ & $62.67 \pm 1.45$ & $17.67 \pm 1.45$ \\
4 & $85.33 \pm 0.88$ & $103.33 \pm 0.88$ & $117 \pm 1.15$ & $121.67 \pm 1.20$ \\
5 & $73.33 \pm 1.45$ & $93.66 \pm 1.45$ & $99.67 \pm 1.76$ & $115 \pm 1.73$ \\
6 & $66.33 \pm 1.45$ & $86.67 \pm 1.20$ & $89.67 \pm 0.88$ & $108.33 \pm 0.88$ \\
7 & $47.33 \pm 1.20$ & $75 \pm 1.00$ & $79 \pm 1.15$ & $99 \pm 1.15$ \\
8 & $41 \pm 1.15$ & $71 \pm 1.15$ & $72 \pm 1.00$ & $92 \pm 1.15$ \\
9 & $34.33 \pm 1.76$ & $75.33 \pm 1.45$ & $78 \pm 1.52$ & $86.67 \pm 0.88$ \\
10 & $28.33 \pm 0.67$ & $51.33 \pm 0.67$ & $64.33 \pm 0.88$ & $74 \pm 2.08$ \\
11 & $23.67 \pm 0.88$ & $45.33 \pm 1.76$ & $59.33 \pm 1.45$ & $64.33 \pm 1.20$ \\
12 & $26.67 \pm 1.45$ & $40 \pm 0.58$ & $51 \pm 0.58$ & $62 \pm 1.00$ \\
13 & $20.67 \pm 0.88$ & $35.33 \pm 0.88$ & $53.33 \pm 0.88$ & $64 \pm 1.15$ \\
14 & $18.33 \pm 0.88$ & $27.33 \pm 1.45$ & $43 \pm 1.16$ & $53.67 \pm 1.45$ \\
15 & $15.33 \pm 0.88$ & $23.33 \pm 1.20$ & $38.67 \pm 0.88$ & $48.67 \pm 0.88$ \\
16 & $12.33 \pm 1.33$ & $15.33 \pm 1.33$ & $33 \pm 1.15$ & $42.67 \pm 1.20$ \\
17 & $10.67 \pm 1.20$ & $10 \pm 1.15$ & $24 \pm 1.53$ & $36.67 \pm 1.20$ \\
18 & $8 \pm 0.58$ & $5.67 \pm 1.20$ & $14.67 \pm 1.45$ & $26 \pm 1.53$ \\
19 & $4 \pm 0.58$ & $2.33 \pm 0.88$ & $5.67 \pm 1.76$ & $11.67 \pm 1.20$ \\
20 & $0 \pm 0$ & $0 \pm 0$ & $0 \pm 0$ & $0 \pm 0$ \\
21 & $0 \pm 0$ & $0 \pm 0$ & $0 \pm 0$ & $0 \pm 0$ \\
Total & 768 & 874 & 985 & 1124 \\
\hline & & & &
\end{tabular}

Appendix Table 4. ANOVA: Single Factor for co-digestion.

\begin{tabular}{llllll}
\hline Source & DF & Squares & Mean Square & F Value & Pr $>$ F \\
Model & 20 & 51153.0794 & 2557.65397 & 671.38 & $<.0001$ \\
Error & 42 & 160 & 3.8095 & & \\
Corrected & 62 & 51313.0794 & & & \\
Total & & & & & \\
\hline
\end{tabular}

$\% \mathrm{CV}=5.99, \mathrm{LSD}=3.2161$

Appendix Table 5. Fisher's least significant difference test for co-digestion

t Grouping Mean N trt




$\begin{array}{llll}\text { A } & 328 & 3 & 75 \% \text { OP+25\% PM } \\ \text { A } & & & \\ \text { A } & 601 & 3 & 50 \% \text { PM+50\% OP } \\ \text { B } & 768 & 3 & 75 \% \text { PM+25\% OP } \\ \text { B } & & & \\ \text { B } & 659.33 & 3 & 100 \% \text { PM } \\ \text { C } & 218.33 & 3 & 100 \% \text { OP }\end{array}$

N.B. Means with the same letter are not significantly different.

Appendix Table 6. ANOVA: Single Factor for thermal pre-treatment.

\begin{tabular}{llllll}
\hline Source & DF & Squares & Mean Square & F Value & Pr $>$ F \\
\hline Model & 20 & 96995.2698 & 4849.7635 & 1520.08 & $<0.0001$ \\
Error & 42 & 134 & 3.1905 & & \\
Corrected & 62 & 97129.2698 & & & \\
Total & & & & & \\
& & & & & \\
\hline
\end{tabular}

$\% \mathrm{CV}=3.42, \mathrm{LSD}=2.94$

Appendix Table 7. Fisher's Least Significant Difference test for thermal pre-treatment

\begin{tabular}{llll}
\hline t Grouping & Mean & $N$ & \multicolumn{1}{c}{ trt } \\
\hline$A$ & 1098.33 & 3 & $80^{\circ} \mathrm{C}$ \\
$A$ & & & \\
$A$ & 913.33 & 3 & $60^{\circ} \mathrm{C}$ \\
$B$ & 768 & 3 & control \\
\hline
\end{tabular}

N.B. Means with the same letter are not significantly different.

Appendix Table 8. ANOVA: Single Factor for $\mathrm{NaOH}$ pre-treatment.

\begin{tabular}{cccccc}
\hline Source & DF & Squares & Mean Square & F Value & Pr $>\boldsymbol{F}$ \\
\hline Model & 20 & 75994.38095 & 3799.71905 & 1027.39 & $<0.0001$ \\
Error & 42 & 155.33333 & 3.69841 & & \\
$\begin{array}{c}\text { Corrected } \\
\text { Total }\end{array}$ & 62 & 76149.71429 & & & \\
\hline
\end{tabular}

$\% \mathrm{CV}=4.67, \mathrm{LSD}=3.17$

Appendix Table 9. Fisher's least Significant Difference test for $\mathrm{CaO}$ pre-treatment

\begin{tabular}{llccl}
\hline & t Grouping & Mean & N & trt \\
\hline A & 1124 & 3 & 2.5 \\
B & 985 & 3 & 1.5 \\
C & 874 & 3 & 0.5 \\
& & & \\
C & 768 & 3 & Control \\
\hline
\end{tabular}

N.B. Means with the same letter are not significantly different. 